\title{
Enhanced glucose-induced intracellular signaling promotes insulin hypersecretion: pancreatic beta-cell functional adaptations in a model of genetic obesity and prediabetes.
}

Running title: Increased beta-cell function in ob/ob mice

Esperanza Irles ${ }^{1,2}$, Patricia Ñeco ${ }^{1,2}$, Mónica Lluesma ${ }^{1,2}$, Sabrina Villar-Pazos ${ }^{1,2}$, Junia Carolina Santos-Silva ${ }^{1,3}$, Jean F. Vettorazzi ${ }^{1,3}$, Paloma Alonso-Magdalena ${ }^{1,2}$, Everardo M. Carneiro $^{3}$, Antonio C. Boschero ${ }^{3}$, Ángel Nadal ${ }^{1,2}$, Ivan Quesada ${ }^{1,2, *}$

${ }^{1}$ Instituto de Bioingeniería, Universidad Miguel Hernández, Elche, Spain.

${ }^{2}$ CIBER de Diabetes y Enfermedades Metabólicas Asociadas (CIBERDEM), Spain.

${ }^{3}$ Department of Structural and Functional Biology, Institute of Biology, State University of Campinas (UNICAMP), Campinas, Brazil.

*to whom reprint requests should be addressed:

I. Quesada. Instituto de Bioingeniería, Universidad Miguel Hernández, Avenida de la Universidad s/n, 03202 Elche, Spain. Phone: (+34) 96522 2003. Email: ivanq@umh.es

Keywords: pancreatic beta-cell, diabetes, obesity, calcium signals, electrical activity, insulin secretion. 


\section{ABSTRACT}

Obesity is associated with insulin resistance and is known to be a risk factor for type-2 diabetes. In obese individuals, pancreatic beta-cells try to compensate for the increased insulin demand in order to maintain euglycemia. Most studies have reported that this adaptation is due to morphological changes. However, the involvement of betacell functional adaptations in this process needs to be clarified. For this purpose, we evaluated different key steps in the glucose-stimulated insulin secretion (GSIS) in intact islets from female $o b / o b$ obese mice and lean controls. Obese mice showed increased body weight, insulin resistance, hyperinsulinemia, glucose intolerance and fed hyperglycemia. Islets from $o b / o b$ mice exhibited increased glucose-induced mitochondrial activity, reflected by enhanced $\mathrm{NAD}(\mathrm{P}) \mathrm{H}$ production and mitochondrial membrane potential hyperpolarization. Perforated patch-clamp examination of betacells within intact islets revealed several alterations in the electrical activity such as increased firing frequency and higher sensitivity to low glucose concentrations. A higher intracellular $\mathrm{Ca}^{2+}$ mobilization in response to glucose was also found in $\mathrm{ob} / \mathrm{ob}$ islets. Additionally, they displayed a change in the oscillatory pattern and $\mathrm{Ca}^{2+}$ signals at low glucose levels. Capacitance experiments in intact islets revealed increased exocytosis in individual $o b / o b$ beta-cells. All these up-regulated processes led to increased GSIS. In contrast, we found a lack of beta-cell $\mathrm{Ca}^{2+}$ signal coupling, which could be a manifestation of early defects that lead to beta-cell malfunction in the progression to diabetes. These findings indicate that beta-cells functional adaptations are an important process in the compensatory response to obesity. 


\section{Introduction.}

Obese individuals are at increased risk for type 2 diabetes. Hyperinsulinemia along with low insulin sensitivity are frequently observed in obesity (Kahn et al., 2006). Although insulin resistance is present in most obese subjects, glucose intolerance and hyperglycemia are not necessarily found in these individuals. Indeed, compensatory adaptations in the pancreatic $\beta$-cells usually allow for higher pancreatic insulin release in order to maintain normoglycemic values (Kargar and Ktorza, 2008; Seino et al., 2011). However, when $\beta$-cell compensations fail to adapt to the increasing insulin requirements imposed by insulin resistance, glucose tolerance becomes deteriorated in obese individuals and, eventually, they can develop overt hyperglycemia and type-2 diabetes (Kahn et al., 2006). Several studies in animal models and humans have reported that the enhanced plasma insulin levels observed in insulin-resistant states, like in obesity, are likely related with increases in $\beta$-cell mass (Sachdeva and Stoffers, 2009; Seino et al., 2011; Saisho et al., 2013). In contrast, other studies in non-diabetic obese human subjects have shown that beta-cell mass was only moderately increased (Rahier et al., 2008) compared with controls or that there were no differences (Kou et al., 2013). However, less importance has been attributed to the involvement of the $\beta$-cell function in these compensatory responses (Hull et al., 2005). Consequently, changes in the $\beta$-cell stimulus-secretion coupling remain poorly characterized in obesity (Kargar and Ktorza, 2008; Seino et al., 2011).

Recently, our group reported that $\beta$-cells from high fat diet-induced obese mice display several functional adaptations. In this insulin-resistant state, $\beta$-cell compensations led to insulin hypersecretion, maintaining normal glycemia and glucose tolerance in obese mice (Gonzalez et al., 2013). However, in the progression from normoglycemia to overt diabetes, insufficient $\beta$-cell compensation to insulin resistance 
can result in a prediabetic condition characterized by impaired glucose tolerance and moderate hyperglycemia (Weir and Bonner-Weir, 2004). In order to analyze this prediabetic state, here we aimed to elucidate the functional changes in the $\beta$-cell glucose-stimulated insulin secretion (GSIS) using a model of genetic obesity. The leptin-deficient $o b / o b$ mouse is characterized by marked obesity, insulin resistance, glucose intolerance, moderate hyperglycemia and elevated plasma insulin levels, but they do not develop overt type 2 diabetes (Coleman, 1978). Given that $o b / o b$ mice have larger islets of Langerhans (Bleisch et al., 1952; Gepts et al., 1960; Bock et al., 2003) with a higher proportion of $\beta$-cells (Baetens et al., 1978; Gepts et al., 1960; Westman, 1968a; Westman, 1968b), they have been extensively used as a source of pancreatic islets. Although numerous investigations have used $o b / o b$ islets for $\beta$-cell studies (Hellman, 1965; Hellman, 1970; Bergsten et al., 1994), a detailed analysis of the potential functional adaptations in the different steps of the stimulus-secretion coupling is still lacking. Additionally, most data about the islet function comes from isolated $\beta$ cells (Ahmed and Grapengiesser, 2001; Grapengiesser et al., 1988), an experimental model that can differ from the physiological scenario, as it has been reported using intact islets (Göpel et al., 1999; Göpel et al., 2000; Göpel et al., 2004). In the current study, we show in intact pancreatic ob/ob islets that improved performance in the majority of steps involved in GSIS would account for the high insulin secretion rate characteristic of hyperinsulinemic insulin-resistant conditions, like in obesity. Additionally, the present findings further support the wide plasticity and crucial adaptation of the $\beta$-cell secretory process in the compensatory responses of the endocrine pancreas. 


\section{Material and Methods}

2.1. Animals. All protocols were approved by our Animal Ethics Committee according to national regulations. Five-week-old female ob/ob mice (C57BL/6J background) were purchased from Harlan Laboratories (Barcelona, Spain) and lean female of matched age were used as controls. In electrophysiological experiments, ob/ob female animals (C57BL/6J background) were purchased from Janvier (Janvier Labs, Le Genest sur l'Isle, France). Animals were housed at $22^{\circ} \mathrm{C}$ with a light cycle of 12 hours (8:00 am to 8:00 pm) and had free access to water and standard chow. Experiments were performed when animals were 12 weeks old.

2.2. Plasma measurements and tolerance tests. Glucose and insulin plasma levels were measured by tail bleeding in fed state and during tolerance tests (Gonzalez et al., 2013). Plasma glucose was measured with a commercial glucometer (Accu-Chek) and plasma insulin by a commercial ELISA kit (Crystal Chemical). For the glucose tolerance test, animals were fasted for 12 hours before an intraperitoneal (i.p.) glucose injection (2g/kg). Plasma glucose was measured at 0, 15, 30, 60, 90, 120 and $180 \mathrm{~min}$ and plasma insulin at 0 and $30 \mathrm{~min}$ after the glucose challenge. For the insulin tolerance test, fed animals were subjected to an i.p. insulin injection (1UI/kg) and then, plasma glucose was measured at 0, 15, 30, 45 y 60 min. The HOMA-IR was also calculated as an indicator of insulin resistance: [fasted plasma glucose $(\mathrm{mg} / \mathrm{dL}) *$ fasted plasma insulin (mU/L)] / 405 (Tripathy et al., 2010; Solomon et al., 2014).

2.3. Islet isolation and cell culture. Mice were sacrificed at the age of 12 weeks by cervical dislocation. Islets were isolated by collagenase digestion as previously described (Gonzalez et al., 2013). In some experiments, islets were subjected to trypsin digestion to obtain isolated cells, and then cultured overnight at $37^{\circ} \mathrm{C}$ in RPMI 1640 
(Sigma, Madrid, Spain) supplemented with 10\% fetal bovine serum, $100 \mathrm{IU} / \mathrm{mL}$ penicillin, $0.1 \mathrm{mg} / \mathrm{mL}$ streptomycin and 11mM D-glucose (Quesada et al., 2000).

2.4. Patch-clamp recordings. Electrophysiological measurements were performed from superficial $\beta$-cells in intact islets using an EPC-10 USB patch-clamp amplifier and the Patch Master Software suite (HEKA Elektronic, Lambrecht/Pfatz, Germany). Intact islets were hold by gentle suction applied to the interior of a wide-bore holding pipette as previously reported (Göpel et al., 1999). The perforated-patch configuration was used for the membrane potential recordings (Gonzalez et al., 2013). The pipette solution contained (in mM): $76 \mathrm{~K}_{2} \mathrm{SO}_{4}, 10 \mathrm{NaCl}, 10 \mathrm{KCl}, 1 \mathrm{MgCl}_{2}$, 5 HEPES (pH=7.35 with $\mathrm{KOH}$ ), and $0.24 \mathrm{mg} / \mathrm{mL}$ of the pore-forming antibiotic amphotericin $\mathrm{B}$; the bath solution contained (in mM): $140 \mathrm{NaCl}, 3.6 \mathrm{KCl}, 1.5 \mathrm{CaCl}_{2}, 5 \mathrm{NaHCO}_{3}, 0.5 \mathrm{MgSO}_{4}, 0.5$ $\mathrm{NaH}_{2} \mathrm{PO}_{4}, 10$ HEPES (pH=7.4 with $\mathrm{NaOH}$ ) and D-glucose as indicated. Exocytosis was monitored using the standard whole-cell configuration and recording cell capacitance changes through the sine +DC mode of the Lock-In amplifier included in the Patch Master software (Gonzalez et al., 2013). For these experiments, the pipette solution contained (in mM): $140 \mathrm{CsCl}, 10 \mathrm{NaCl}, 1 \mathrm{MgCl}_{2}$, 0.05 EGTA, 3 Mg-ATP, 0.1 cAMP and 5 HEPES ( $\mathrm{pH}=7.2$ with $\mathrm{CsOH}$ ), whereas the bath solution contained (in $\mathrm{mM}$ ): 118 $\mathrm{NaCl}, 5.6 \mathrm{KCl}$, 20 tetraethylammonium-Cl, $1.2 \mathrm{MgCl}_{2}$, $5 \mathrm{CaCl}_{2}$, 5 HEPES and 5 Dglucose ( $\mathrm{pH}=7.4$ with $\mathrm{NaOH})$. Only experiments with stable and low access resistance and small leak currents were used. The seal resistance was typically $>3 \mathrm{M} \Omega$. All experiments were carried out at physiological temperature $\left(34-36^{\circ} \mathrm{C}\right) . \beta$-cells were functionally identified by the ability to generate the characteristic oscillatory electrical activity in the presence of glucose and steady-state inactivation of $\mathrm{Na}^{+}$currents (Göpel et al., 1999; Göpel et al., 2000; Gonzalez et al. 2013). 


\subsection{Intracellular $\mathrm{Ca}^{2+}, \mathrm{NAD}(\mathrm{P}) \mathrm{H}$ and mitochondrial membrane potential}

123

124

125

126

127

measurements. Isolated islets were allowed to recover in the isolation medium for at least 2 hours at $37^{\circ} \mathrm{C}$ and $5 \% \mathrm{CO}_{2}$ before experiments. For intracellular calcium $\left(\left[\mathrm{Ca}^{2+}\right]_{\mathrm{i}}\right)$ recordings, islets were incubated for $1 \mathrm{~h}$ at room temperature with $2 \mu \mathrm{M}$ fura- 2 (for conventional fluorescence microscopy) or fluo-4 (for confocal microscopy). For intact islet $\mathrm{Ca}^{2+}$ signaling, recordings were performed under an inverted epifluorescence microscope (Axiovert 200; Zeiss, Jena, Germany) equipped with 360 and 380nm bandpass filters. Recordings were expressed as the ratio of fluorescence at 360 and 380 (F360/380). Images were taken every 3 seconds. Intracellular $\left[\mathrm{Ca}^{2+}\right]$ changes in response to stimuli were analyzed as previously described (Rafacho et al., 2010). For transient changes in $\left[\mathrm{Ca}^{2+}\right]_{\mathrm{i}}$, the basal fluorescence $\left(\mathrm{F}_{0}\right)$ was subtracted to the maximal fluorescence and expressed as $\Delta \mathrm{F}\left(\mathrm{F}-\mathrm{F}_{0}\right)$. Additionally, as a measure of global $\left[\mathrm{Ca}^{2+}\right]_{\mathrm{i}}$ increase, the area under the curve (AUC) was calculated on the last five minutes of each glucose stimulus. Changes in $\mathrm{NAD}(\mathrm{P}) \mathrm{H}$ autofluorescence and mitochondrial membrane potential $\left(\Delta \Psi_{\mathrm{m}}\right)$ were monitored with the above-mentioned imaging system (Rafacho et al., 2010). For NAD(P)H autofluorescence, a 365nm band-pass filter was used, and emission was filtered at $445 \pm 25 \mathrm{~nm}$. Images were acquired every 60 seconds. For measurement of $\mathrm{NAD}(\mathrm{P}) \mathrm{H}$ in isolated cells, cells were cultured overnight in RPMI 1640. Recordings were plotted as the increase of fluorescence referred to the fluorescence in the basal condition. $\Delta \Psi_{\mathrm{m}}$ was measured after loading fresh isolated islets for 10 minutes with $10 \mu \mathrm{M}$ rhodamine-123 (Rhod-123). Images were taken every 30 seconds using conventional fluorescein filters. Recordings were plotted as the decrease of fluorescence relative to the fluorescence in the basal condition. For the analysis of $\beta$-cell synchrony, whole islets were used to monitor changes in $\left[\mathrm{Ca}^{2+}\right]_{\mathrm{i}}$ 
within individual cells using a confocal microscope (Zeiss LSM510 laser), as previously reported (Gonzalez et al., 2013; Quesada et al., 2006).

2.6. Insulin secretion and content. Isolated islets recovered in the isolation medium for $2 \mathrm{~h}$ in the incubator $\left(37^{\circ} \mathrm{C} ; 5 \% \mathrm{CO}_{2}\right)$. After recovery, batches of 5 islets were exposed to the different glucose stimuli and allowed to secrete for $1 \mathrm{~h}$ at $37^{\circ} \mathrm{C}$ (solution composition in mM: $\left.140 \mathrm{NaCl}, 4.5 \mathrm{KCl}, 2.5 \mathrm{CaCl}_{2}, 1 \mathrm{MgCl}_{2}, 20 \mathrm{HEPES}, \mathrm{pH}=7.4\right)$. The totality of the secretion volume $(500 \mu \mathrm{L})$ was collected and then measured by RIA, in duplicate, using a Coat-a-Count kit (Siemens, Los Angeles, California). The groups of 5 islets were transferred to an ethanol/HCl buffer to promote cell lysis. After overnight incubation at $4^{\circ} \mathrm{C}$, the supernatant was used to quantify insulin content by RIA and total protein by the Bradford method. Insulin secretion was expressed normalized either by insulin content or total protein, as previously shown (Gonzalez et al., 2013).

2.7. Quantitative real-time PCR. Total RNA from islets of Langerhans was isolated using the RNeasy Plus Mini Kit (Qiagen) and the RNA concentration was determined from 500ng of total RNA using the High Capacity cDNA Reverse Transcription Kit (Applied Biosystems). Quantitative PCR reactions were performed using the CFX96 Real Time System (Bio-Rad, Hercules, California). Reactions were carried out in a final volume of $10 \mu \mathrm{L}$, containing $200 \mathrm{nM}$ of each primer, $1 \mu \mathrm{L}$ of cDNA and $1 \mathrm{X}$ of $\mathrm{iQ}^{\mathrm{TM}}$ SYBR ${ }^{\circledR}$ Green supermix (Bio-Rad). Samples were subjected to the following thermal cycler conditions: $10 \mathrm{~min}$ at $95^{\circ} \mathrm{C}, 45$ cycles $\left(10\right.$ s at $95^{\circ} \mathrm{C}, 7 \mathrm{~s}$ at $60^{\circ} \mathrm{C}, 15 \mathrm{~s}$ at $\left.72^{\circ} \mathrm{C}\right)$ and melting curve from 65 to $95^{\circ} \mathrm{C}$ with a slope of $0.1^{\circ} \mathrm{C} / \mathrm{s}$. The gene for relative quantification was GAPDH. The resulting values were analyzed with CFX Manager version 1.6 (Bio-Rad) and values were expressed as the relative expression respect to control levels $\left(2^{-\Delta \Delta C t}\right)$. Primer sequences are described in Supplemental Table 1. 
171 2.8. Western blot. Groups of 200-300 islets were subjected to lysis in $20 \mu \mathrm{L}$ of Cell

172 Lysis Buffer (Cell Signaling Technology, Danvers, MA). For SDS gel electrophoresis

173 and Western blot analysis, samples were treated with a Laemmli sample buffer

174 containing dithiothreitol. After heating at $95^{\circ} \mathrm{C}$ for 5 minutes, proteins were separated

175 by electrophoresis in a 4-20\% Mini Protean Gel (Bio Rad). Prestained SDS-PAGE

176 standards were included for molecular mass estimation. Transfer to PVDF membranes

177 was performed in a Trans Blot Turbo transfer for 7 minutes in 25V, with TRIS/Glycine

178 buffer (Bio Rad). After membranes were blocked with 5\% non-fat dry milk buffer, they

179 were incubated with a polyclonal antibody against Connexin36 (1:1000; Invitrogen) or

$180 \quad \beta$-Tubulin (1:1000; Cell Signaling). Visualization of specific protein bands was

181 performed by incubating the membranes with appropriate secondary antibodies. Protein

182 bands were revealed by using the Chemi Doc MP System (Bio Rad). The band

183 intensities were quantified with the Image Lab Lale 4.1 TM Software (Bio Rad).

184 2.9. Measurement of islet size. The pancreas was extracted and fixed in $4 \%$ 185 paraformaldehyde. The tissue was then processed and embedded in paraffin and 186 sections were prepared. Staining was performed as previously described (Gonzalez et 187 al., 2013). The area of pancreatic islets was analyzed using the Metamorph Software 188 (Molecular Devices, Sunnyvale, CA).

189 2.10. Data analysis. Data are shown as mean \pm SE unless otherwise stated. Statistical 190 comparisons between groups were performed using the unpaired Student's $t$-test, with 191 Welch's correction when mandatory. Differences were considered significant when p < $192 \quad 0.05$. 
3.1. Metabolic features in $o b / o b$ mice related with glucose homeostasis. Twelveweek old $o b / o b$ mice displayed an increased body weight that was twice that of agematched CTL (controls; Fig. 1A) (40.82 \pm 0.43 g vs $20.77 \pm 0.15$ g, respectively). Obese mice exhibited increased plasma glucose concentrations in the fed state (Fig. 1B), despite the high levels of fed plasma insulin compared with controls (Fig. 1C). Additionally, ob/ob mice were insulin resistant (Fig. 1D; Supplemental Fig. 1) and glucose intolerant (Fig. 1E). The glucose tolerance test (Fig. 1E, F) showed that fasting plasma glucose tended to be higher in ob/ob mice (although not statistically significant), and that these obese animals displayed glucose intolerance, as evidenced by the high plasma glucose levels maintained over the 3 hours subsequent to the glucose challenge. In the control group, plasma glucose clearance reached basal levels after 90-120 min, whereas in the obese group plasma glucose remained elevated even after $180 \mathrm{~min}$. Finally, after an i.p. glucose load, plasma insulin levels were found higher at 0 and 30 min in $o b / o b$ mice (Fig. 1G, H). Altogether, these results indicate that, although $o b / o b$ mice exhibit higher insulin responses to glucose changes, this adaptation would not fully compensate the requirements imposed by insulin resistance to maintain normoglycemia. Thus, since $o b / o b$ mice represent a good model to study this prediabetic state characterized by insulin resistance and glucose intolerance, we aimed to study the different steps involved in GSIS.

3.2. Enhanced mitochondrial function in $o b / o b$ islets. Glucose metabolism yields redox power by means of nicotinamide adenine dinucleotide (NADH) and flavin adenine dinucleotide $\left(\mathrm{FADH}_{2}\right)$ production (Quesada et al., 2006). This reducing power, mainly produced by the tricarboxylic acid cycle in the mitochondria, is used as a source for electron transfer in the oxidative phosphorylation required to produce ATP (Quesada 
et al., 2006; Rafacho et al., 2010). In an attempt to monitor changes in the mitochondrial redox state induced by glucose metabolism, we performed $\mathrm{NAD}(\mathrm{P}) \mathrm{H}$ autofluorescence experiments in CTL and ob/ob intact islets. As shown in Figure 2A, increasing glucose concentrations produced gradual increments in $\mathrm{NAD}(\mathrm{P}) \mathrm{H}$ fluorescence in both groups. Interestingly, $o b / o b$ islets showed an enhanced $\mathrm{NAD}(\mathrm{P}) \mathrm{H}$ production at each glucose concentration tested (Fig. 2B). When the data was normalized to calculate the glucose concentration required to reach the half maximal fluorescence, we found that the glucose dose-response curve was shifted to lower glucose concentrations in $o b / o b$ islets (CTL: $8.77 \mathrm{mM} \mathrm{G}$; ob/ob: 6.77mM G) (Fig. 2C). To further confirm the increased mitochondrial activity in islets from obese mice, we monitored changes in the mitochondrial membrane potential $\left(\psi_{\mathrm{m}}\right)$, as this parameter depends on glucose metabolism. Increasing glucose concentrations lead to $\psi_{\mathrm{m}}$ hyperpolarization (Rafacho et al., 2010). To monitor $\psi_{\mathrm{m}}$, we loaded islets with the lipophylic fluorescent dye rhodamine-123 (Rhod-123), which intercalates into the mitochondrial membranes in a potential-dependent manner. Figure 2D shows the typical gradual decrease in Rhod-123 fluorescence, when glucose concentrations were stepwise increased. In agreement with the results obtained with $\mathrm{NAD}(\mathrm{P}) \mathrm{H}$ fluorescence, $o b / o b$ islets exhibited a higher $\psi_{\mathrm{m}}$ hyperpolarization at all the glucose concentrations (Fig. 2D and E). When Rhod-123 fluorescence was normalized in both groups to obtain the glucose concentration associated to the half maximal fluorescence, we did not get differences between both groups (Fig. 2F). This might probably due to the lower sensitivity of this experiment to produce glucose-mediated fluorescence compared with the NAD(P)H assays (Fig. 2A, D). Consistent with the rest of results, we also found enhanced NAD(P)H production in 241 isolated $\beta$-cells from ob/ob mice (Fig. 2G, H). This improved glucose-induced 242 mitochondrial response in $o b / o b$ islets might not be associated with up-regulation of 
early metabolic steps, since we found decreased glucose transporter-2 expression in $o b / o b$ islets ( 68\% decrease vs CTL) and comparable levels of glucokinase gene expression in both groups (Supplemental Fig. 2).

\subsection{Obese mice display several alterations in the membrane potential of $\beta$-cells.}

The following experiments were performed using perforated-patch recordings in $\beta$-cells within intact islets to preserve the cell-to-cell environment, which is more similar to the physiological scenario (Göpel et al., 1999; Göpel et al., 2000; Göpel et al., 2004). Compared with the characteristic membrane potential oscillations in response to $11 \mathrm{mM}$ glucose in controls (Fig. 3A), ob/ob $\beta$-cells displayed a different profile (Fig. 3B). In $o b / o b$, the firing frequency of the action potentials was slightly increased (Fig. 3C), in combination with a much longer duration of the burst (Fig. 3D) and longer silent phases between bursts (Fig. 3E). Interestingly, a more detailed analysis of the membrane potential recordings (Fig. 3F,G) showed that the burst was initiated at less negative potentials in $\beta$-cells from obese mice (CTL, $-71.7 \pm 1.9 \mathrm{mV}$; ob/ob, $-57.2 \pm 2.7 \mathrm{mV}$ ) (Fig. 3H). Furthermore, the action potentials of $o b / o b \beta$-cells started at a more depolarized potential (CTL, $-47,5 \pm 2,2 \mathrm{mV}$; ob/ob, $-39,8 \pm 1,8 \mathrm{mV}$ ) (Fig. 3I) and peaks reached less negative potentials (CTL, -24,1 $\pm 2,9 \mathrm{mV}$; ob/ob, $-12,1 \pm 2,2 \mathrm{mV}$ ) (Fig. 3J). As we will discuss later, this different electrical activity in $o b / o b$ mice, particularly the higher frequency and burst duration, should have an impact on $\mathrm{Ca}^{2+}$ signaling, since action potentials in mouse $\beta$-cells are mainly mediated by $\mathrm{Ca}^{2+}$ channels (Göpel et al., 1999; Rorsman and Braun, 2013).

\subsection{Islets from obese mice exhibit enhanced glucose-induced $\mathrm{Ca}^{2+}$ signals. $\mathrm{Ca}^{2+}$} signaling plays a key role in coupling glucose metabolism and insulin release. As a next step in the $\beta$-cell stimulus-secretion process, we analyzed intracellular $\mathrm{Ca}^{2+}$ signals in whole islets, as previously described (Rafacho et al., 2010; Gonzalez et al., 2013). 
268 While $\mathrm{ob} / \mathrm{ob}$ islets displayed an enlarged $\mathrm{Ca}^{2+}$ signal in response to 5.6 and $8 \mathrm{mM}$ 269 glucose compared with controls, no differences were found at $16 \mathrm{mM}$, when the AUC 270 was calculated as a measure of the global $\mathrm{Ca}^{2+}$ entry (Fig. 4A-C). This analysis 271 evidenced that the $\mathrm{Ca}^{2+}$ signal in $\mathrm{ob} / \mathrm{ob}$ islets at $5.6 \mathrm{mM}$ glucose was of the same 272 magnitude than that of CTL islets at 8mM glucose. A similar equivalence was observed 273 between the intracellular $\mathrm{Ca}^{2+}$ in $\mathrm{ob} / \mathrm{ob}$ islets at $8 \mathrm{mM}$ glucose and CTL islets at $16 \mathrm{mM}$ 274 glucose (Fig. 4C). When we analyzed the fluorescence increase $(\Delta \mathrm{F})$ of the first $\mathrm{Ca}^{2+}$ transient at each glucose stimulus, differences were only found at 5.6mM glucose (Fig. 4D). This was related to the fact that the totality of $\mathrm{ob} / \mathrm{ob}$ islets displayed $\mathrm{Ca}^{2+}$ signaling 277 at this glucose concentration, whereas in most of the CTL islets any $\mathrm{Ca}^{2+}$ entry was 278 detected (Fig. 4E). The oscillatory pattern was also modified in islets from obese mice. While CTL islets showed the characteristic pattern with oscillations of high frequency after the first transient at $8 \mathrm{mM}$ glucose, $\mathrm{ob} / \mathrm{ob}$ islets showed lower frequency $\mathrm{Ca}^{2+}$ signals (Fig. 4F). We next analyzed the response to a stimulus independent of metabolism. Exposure to $75 \mathrm{mM} \mathrm{KCl}$ led to a depolarization-induced $\mathrm{Ca}^{2+}$ transient (Fig. 4G). The amplitude of this transient was not different between both groups (Fig. 4H), suggesting that increased $\mathrm{Ca}^{2+}$ signaling in obese mice were due to changes in glucose metabolism. The non-glucidic fuel alpha-ketoisocaproate (KIC) has been shown to produce $\mathrm{Ca}^{2+}$ oscillations in pancreatic islets (Martin et al., 1995). KIC also led to enhanced $\mathrm{Ca}^{2+}$ signaling in islets from obese mice compared with lean controls

288 (Supplemental Fig. 3), further suggesting that metabolism is particularly affected in 289 ob/ob animals. In summary, glucose-regulated $\mathrm{Ca}^{2+}$ signaling in $\mathrm{ob} / \mathrm{ob}$ islets was mainly characterized by higher magnitude and higher sensitivity to glucose compared with controls. 

gene expression (Fig. 5A) as well as insulin content (Fig. 5B) were found to be increased in $o b / o b$ islets as compared to CTL. As previously documented (Black et al., 1986; Fournier et al., 1990), we observed that insulin secretion was enhanced in islets from obese mice (Supplemental Fig. 4). Since it has been reported that the exocytotic process measured in isolated $\beta$-cells largely differs from that measured in islets (Göpel et al., 2004), we studied exocytosis in $\beta$-cells within the pancreatic islets, which better resembles the physiological cell-to-cell interactions. When we analyzed capacitance changes in response to depolarization pulses, we found that exocytosis in $o b / o b \beta$-cells was higher than in CTL cells (Fig. 5C, D), indicating that enhanced insulin secretion in intact islets is also due to augmented exocytosis at the single cell level.

3.6. $\boldsymbol{\beta}$-cell coupling is altered in the islets of obese mice. Analysis of intracellular $\mathrm{Ca}^{2+}$ signals in individual $\beta$-cells within the pancreatic islets, as reported previously (Gonzalez et al. 2013), showed that cell-to-cell coupling was reduced in $o b / o b \beta$-cells compared with controls (Fig. 6A, B). When the lag time was calculated between the first and the last beta-cell responding with a $\mathrm{Ca}^{2+}$ increase to $11 \mathrm{mM}$ glucose within a single islet, we observed that the average time was $58.04 \pm 9.14$ seconds in $o b / o b$ islets and $4.68 \pm 1.34$ seconds in CTL islets (Fig. 6C), indicating a lower synchrony in the former group. While connexin36 mRNA levels were similar in both groups, the protein content was significantly reduced in $o b / o b$ islets (Supplemental Fig. 5). Gap junctions in the mouse $\beta$-cell are mainly composed by Cx36. Additionally, we found that ob/ob $\beta$ cells responded $1.35 \pm 0.15 \mathrm{~min}$ faster to $11 \mathrm{mM}$ glucose than control cells (Fig.6D), which is consistent with the higher glucose sensitivity observed in the previous experiments (Fig. 2,4). 
During obesity, the endocrine pancreas undergoes several adaptations to compensate for the insulin resistance characteristic of this state. Structural adaptations, by means of an increment in the $\beta$-cell mass, have been extensively reviewed in both animals and humans (Butler et al., 2003; Sachdeva et al., 2009; Seino et al., 2011; Saisho et al. 2013). In agreement with previous reports in ob/ob mice (Bock et al., 2003), we also found increased islet size (Supplemental Fig. 6). However, less is known about the $\beta$-cell functional adaptations (Kahn et al., 2006; Kargar and Ktorza, 2008; Seino et al., 2011). We have previously demonstrated in a model of high fat dietinduced obesity that pancreatic $\beta$-cells exhibit an improved function in several events involved in GSIS (Gonzalez et al., 2013). These adaptations allowed for a compensation of insulin resistance, preserving normoglycemia and glucose tolerance in this model. It has been proposed that, in the progression from this normoglycemic state to overt diabetes in obese subjects, compensatory adaptations become insufficient to counteract insulin resistance, leading to an intermediate state characterized by hyperinsulinemia, moderate hyperglycemia and glucose intolerance (Weir and Bonner-Weir, 2004). However, there is no information about this prediabetic condition at the functional level. In the present study, we have taken advantage of the $o b / o b$ mouse metabolic characteristics, which resemble this prediabetic state, to explore the $\beta$-cell function. At the age of 12 weeks, ob/ob mice exhibited glucose intolerance and insulin resistance, in agreement with previous publications (Saleh et al., 2006). Despite the high circulating insulin levels, obese mice were only able to maintain plasma glucose levels within the normoglycemic range in the fasted state but not during fed conditions or during an i.p.

340 glucose challenge (Fig. 1). Although the hyperinsulinemic characteristic of $o b / o b$ mice has been related with morphological adaptations (Tomita et al., 1992; Baetens et al., 
1978; Gepts et al., 1960), increased GSIS has been also observed in isolated ob/ob islets

343 (Black et al., 1986; Fournier et al., 1990. Saleh et al., 2006). In the present work, we focused on the involvement of the different functional steps participating in GSIS.

In $\beta$-cells, most of the $\mathrm{NAD}(\mathrm{P}) \mathrm{H}$ synthesis derived from glucose metabolism takes place in the mitochondria (Patterson et al., 2000). We showed here an enhanced NAD(P)H production and glucose sensitivity in islets of obese mice (Fig. 2). This effect was also observed in individual $\beta$-cells, which supports that the enhanced $\mathrm{NAD}(\mathrm{P}) \mathrm{H}$ signal found in intact islets would not be due to increased $\beta$-cell number but a consequence of metabolic adaptations in individual $\beta$-cells. Additionally, $o b / o b$ islets displayed higher glucose-induced $\psi_{\mathrm{m}}$ hyperpolarization, further supporting an enhanced $\beta$-cell mitochondrial performance in obese mice. All these findings are in agreement with previous reports showing similar metabolic responses in a rat model of insulin resistance (Rafacho et al., 2010). Since enhanced $\mathrm{NAD}(\mathrm{P}) \mathrm{H}$ production and $\Psi_{\mathrm{m}}$ hyperpolarization should be coupled to increased ATP synthesis (Quesada et al., 2006), the mitochondrial responses in $o b / o b$ islets and their higher glucose sensitivity may explain the electrical activity at lower glucose levels compared with controls (Fig. 3). Likewise, since $\beta$-cell $\mathrm{Ca}^{2+}$ signaling is mediated by electrical activity, the intracellular $\mathrm{Ca}^{2+}$ entry observed at $5.6 \mathrm{mM}$ glucose in $\mathrm{ob} / \mathrm{ob}$ islets (Fig. 4) would be also associated with the improved mitochondrial activity. In addition to electrical and $\mathrm{Ca}^{2+}$ signaling effects, it has been shown that ATP and other glucose-stimulated mitochondrial factors like glutamate and, particularly, $\mathrm{NAD}(\mathrm{P}) \mathrm{H}$ can also exert a positive regulation of exocytosis and secretory granules mobilization (Maechler and Wollheim, 1999; Ivarsson et al., 2005; Reinbothe et al., 2009; MacDonald, 2011; Rorsman and Braun, 2013). Thus, all these cellular events are expected to be augmented in ob/ob $\beta$-cells. 
expression was not altered (Supplemental Fig. 2). Despite the decreased GLUT2 expression, which has also been reported at the protein level in ob/ob islets (Jetton et al, 2001), glucose metabolism is not necessarily affected by this alteration, since the limiting enzyme in the glycolytic pathway is GcK (Chen et al., 1994). Thus, the enhanced mitochondrial activity shown in $o b / o b \beta$-cells might result from alterations other than in these proteins.

It has been previously reported that glucose usage is mainly glycolytic in the pancreatic beta-cell and that glucose-induced $\mathrm{NAD}(\mathrm{P}) \mathrm{H}$ fluorescence comes fundamentally from mitochondria rather than from cytosol in the pancreatic islet 376 (Patterson et al., 2000; Quesada et al., 2006). Thus, this protocol allows for the temporal analysis of mitochondrial activity. Our results indicate a left-shift displacement in the dose-response curve of the glucose-induced $\mathrm{NAD}(\mathrm{P}) \mathrm{H}$ fluorescence (Fig. 2C), indicating a higher sensitivity for low and intermediate glucose levels in obese animals, as previously indicated (Chen et al., 1993). A similar finding was found in glucoseinduced $\mathrm{Ca}^{2+}$ signals (Fig. 4). The NAD(P)H results are in agreement with previous findings showing increased ATP production at low glucose concentrations in islets of ob/ob mice compared with lean controls, while no significant differences were observed at high glucose levels (Saleh et al., 2006). In this study, it was also reported that ob/ob islets express more uncoupling protein-2 (UCP2) than controls, which may contribute to GSIS impairment (Saleh et al., 2006). Given that UCP2 activation is associated with $\Psi_{\mathrm{m}}$ dissipation (Fink et al., 2002), our experiments (Fig. 2D-F) argue against a negative impact of this protein on beta-cell $\Psi_{\mathrm{m}}$ in ob/ob mice.

$\beta$-cells from $o b / o b$ mice display an electrical activity pattern that differs from that of controls, as it has been previously reported (Rosario et al., 1985). Among other features, this electrical pattern is characterized by a higher sensitivity to low glucose 
concentrations. This hyper-excitability has been related to altered $\mathrm{K}^{+}$permeabilities

393 (Fournier et al., 1990; Rosario, 1985). These observations would be in accordance with the lower density of $\mathrm{K}_{\mathrm{ATP}}$ channels in the membrane of $\beta$-cells from $o b / o b$ mice (Park et al., 2013). Alternatively, here we show that the improved glucose-induced electrical activity in $o b / o b$ islets may be also explained by their enhanced mitochondrial activity at lower glucose concentrations (Fig. 2), in agreement with previous works (Saleh et al., 2006). Additionally, in line with other studies (Rosario et al., 1985), the firing frequency and the duration of the electrical activity bursts were increased in obese mice (Fig. 3). Both characteristics would be associated with the higher $\mathrm{Ca}^{2+}$ signals observed in $o b / o b$ islets (Fig. 4), given that action potentials in mouse $\beta$-cells result from $\mathrm{Ca}^{2+}$ channel activity, which lead to $\mathrm{Ca}^{2+}$ entry (MacDonald, 2011). Moreover, the burst and action potential baseline were slightly depolarized compared with controls (Fig. 4), which may suggest an altered activity of $\mathrm{Ca}^{2+}$-activated $\mathrm{K}^{+}$channels, as previously indicated (Rosario et al., 1985; Rosario, 1985; Black et al., 1988). It has been reported that higher action potentials may be associated to increased inward $\mathrm{Ca}^{2+}$ currents due to the voltage-dependence characteristics of $\mathrm{Ca}^{2+}$ channels (Gonzalez et al., 2013; Houamed et al., 2010; Jacobson et al., 2010). Thus, it is possible that the higher peak level of the ob/ob action potentials (Fig. 3J) may also contribute to the increased $\mathrm{Ca}^{2+}$ signals shown here (Fig. 4). ob/ob mice (Fig. 4). Other studies have not reported differences, probably because ob/ob islets were stimulated by glucose concentrations $(20 \mathrm{mM})$ at which $\beta$-cells were 414 maximally depolarized (Fournier et al., 1993). In contrast to the glucose effects, no 415 differences were found by $\mathrm{KCl}$ stimulation, which further supports the idea that 416 increased $\mathrm{Ca}^{2+}$ signals in $\mathrm{ob} / \mathrm{ob}$ islets may be mediated by changes in glucose 
417 metabolism or metabolic-related factors (Ivarsson et al., 2005; MacDonald, 2011;

418 Rorsman and Braun, 2013), particularly at low-intermediate glucose levels. The idea 419 that metabolism could be affected in ob/ob islets was also supported by the higher 420 response to KIC. As we have mentioned above, the enhanced $\mathrm{Ca}^{2+}$ signals would be also 421 related to the higher action potential frequency and longer burst duration characteristic 422 of $o b / o b$ beta-cells. Additionally, most $o b / o b$ islets displayed a different oscillatory pattern, characterized by the loss of high frequency oscillations (Fig. 4). This has been attributed to a reduced expression of the TRPM5 channel (Colsoul et al., 2010; Colsoul et al., 2013). Our findings in TRPM5 gene expression agree with this effect on the $\mathrm{Ca}^{2+}$ oscillatory frequency (Supplemental Fig. 2). This channel is a non-selective monovalent cation channel activated by intracellular $\mathrm{Ca}^{2+}$ that contributes to membrane depolarization during electrically silent intervals, promoting the initiation of a new burst activity. This would also explain the absence of fast membrane potential oscillations in ob/ob (Fig. 3), as described for Trpm5 $5^{-/-}$islets (Colsoul et al., 2010). However, Colsoul et al. found no differences between controls and $\operatorname{Trpm} 5^{-/-}$islets in the glucose concentration threshold that trigger $\left[\mathrm{Ca}^{2+}\right]_{\mathrm{i}}$ oscillations. In ob/ob islets, this might be explained by the lower $\mathrm{K}_{\mathrm{ATP}}$ density in the plasma membrane (Park et al., 2013) and an enhanced glucose metabolism, as we showed here.

The increased insulin secretory capacity in $o b / o b$ islets has been reported long time ago (Black et al., 1986; Fournier et al., 1990). Our capacitance experiments in intact islets demonstrate that this hypersecretion may be supported by an enhanced exoytotic capacity at the single cell level. Additionally, given that capacitance changes were elicited by depolarization pulses (instead of glucose stimuli), it also indicates that 440 the exocytotic process per se is subjected to an adaptive process in ob/ob $\beta$-cells independent of glucose metabolism that would increase the secretory process. In any 
case, since it has been reported that $\mathrm{NAD}(\mathrm{P}) \mathrm{H}$ can directly affect $\beta$-cell exocytosis

443 (Ivarsson et al., 2005; Reinbothe et al., 2009), the increased NAD(P)H responses

444 reported here might be also involved in the augmented exocytosis in ob/ob $\beta$-cells. In

445 line with other reports (Saleh et al., 2006), we also observed enhanced insulin secretion

446 at low glucose concentrations in ob/ob islets (Supplemental Fig. 4), although no

447 differences were found in $\mathrm{Ca}^{2+}$ levels. This augmented basal secretion may be due to

448 up-regulated constitutive insulin secretion or that beta-cell secretory granules contain

449 more insulin compared with controls. However, much research would be necessary to

450 explore these possibilities. It has been proposed that GSIS is modulated by both

451 triggering and metabolic amplifying pathways (Henquin, 2009), that are mainly relayed

452 by $\mathrm{Ca}^{2+}$ and metabolic factors, respectively. Although we did not perform specific

453 experiments in the current study to understand the potential contribution of each

454 pathway in the augmented GSIS in ob/ob islets, several findings such as the elevated

$455 \mathrm{Ca}^{2+}$ levels and mitochondrial function suggest that both pathways might be involved.

Cell-to-cell coupling among $\beta$-cells allows electrical and $\mathrm{Ca}^{2+}$ signaling synchrony within the islet (Nadal et al., 1999; Quesada et al., 2006). This coupling is necessary to maintain a proper insulin secretion and alterations in this coordination are detrimental for this process (Vozzi et al., 1995; Charollais et al., 2000). We observed 460 decreased $\mathrm{Ca}^{2+}$ signal coupling among $\beta$-cells of $\mathrm{ob} / \mathrm{ob}$ islets in agreement with previous studies (Ravier et al., 2002). Connexin36, which is the main connexin type expressed in mouse islets, was reduced at the protein level in ob/ob islets compared with controls. Thus, this protein reduction may contribute to the deficient coupling observed in obese islets. Additionally, given that electrical and $\mathrm{Ca}^{2+}$ signal transmission within the islet 465 decay with the intercellular distance (Andreu et al., 1997; Quesada et al., 2003), it is plausible that the decreased coupling in $o b / o b$ islets are also associated with their larger 
467 size compared with controls (Gepts et al., 1960; Baetens et al., 1978; Tomita et al., 468 1992), as it has been previously suggested (Ravier et al., 2002). This possibility would 469 require further investigation. Thus, among the different events studied in the present work, $\mathrm{Ca}^{2+}$ signal coupling was the only one to be decreased. Since we have previously observed normal coupling in islets of obese normoglycemic mice (Gonzalez et al., 472 2013), it is tempting to speculate that this could be an early defect in the prediabetic state that takes place in the progression to diabetes in obese individuals.

In summary, while the islet compensatory response to obesity and insulin resistant states has been mainly related to morphological changes, here we show that $\beta$ cell functional adaptations have also a key role in this process. Additionally, we also demonstrated that almost all the events implicated in GSIS are augmented in magnitude and/or glucose sensitivity, indicating a significant plasticity in $\beta$-cell function in nonphysiological and pathological conditions. Finally, we also detected a lack of $\beta$-cell coordination in obese prediabetic mice that could be an early manifestation of functional defects that lead to GSIS failure and diabetes. All these adaptations may offer a broad spectrum of possibilities for the design of therapeutic approaches that may slow down the progression to diabetic states in obese individuals.

Acknowledgements. We thank M. S. Ramon and M. L. Navarro for their expert technical assistance. This work was supported by grants from the Spanish Ministerio de Ciencia e Innovación (BFU2013-42789-P; BFU2011-28358), Generalitat Valenciana (PROMETEO/2011/080), and the European Foundation for the Study Diabetes 489 (EFSD/BI Basic Programme). CIBERDEM is an initiative of the Instituto de Salud 490 Carlos III. 
492 Disclosure Summary: The authors have nothing to disclose.

493

494 


\section{References}

Ahmed, M., Grapengiesser, E., 2001. Pancreatic beta-cells from obese-hyperglycemic mice are characterized by excessive firing of cytoplasmic $\mathrm{Ca} 2+$ transients. Endocrine. 15(1):73-8.

Andreu, E., Soria, B., Sanchez-Andres, J.V., 1997. Oscillation of gap junction electrical coupling in the mouse pancreatic islets of Langerhans. J Physiol. 498 (Pt 3):753-61.

Baetens, D., Stefan, Y., Ravazzola, M., Malaisse-Lagae, F., Coleman, D.L., Orci, L., 1978. Alteration of islet cell populations in spontaneously diabetic mice. Diabetes. 27(1):1-7.

Bergsten, P., Grapengiesser, E., Gylfe, E., Tengholm, A., Hellman, B., 1994. Synchronous oscillations of cytoplasmic $\mathrm{Ca} 2+$ and insulin release in glucosestimulated pancreatic islets. J Biol Chem. 269(12):8749-53.

Black, M.A., Fournier, L.A., Heick, H.M., Bégin-Heick, N., 1988. Different insulinsecretory responses to calcium-channel blockers in islets of lean and obese (ob/ob) mice. Biochem J. 249(2):401-7.

Black, M., Heick, H.M., Bégin-Heick, N., 1986. Abnormal regulation of insulin secretion in the genetically obese (ob/ob) mouse. Biochem J. 238(3):863-9.

Bleisch, V.R., Mayer, J., Dickie, M.M., 1952. Familial diabetes mellitus in mice, associated with insulin resistance, obesity, and hyperplasia of the islands of langerhans. Am J Pathol. 28(3):369-85.

Bock, T., Pakkenberg, B., Buschard, K., 2003. Increased islet volume but unchanged islet number in ob/ob mice. Diabetes 52:1716-22.

Butler, A.E., Janson, J., Soeller, W.C., Butler, P.C., 2003. Increased beta-cell apoptosis prevents adaptive increase in beta-cell mass in mouse model of type 2 diabetes: evidence for role of islet amyloid formation rather than direct action of amyloid. Diabetes. 52(9):2304-14.

Charollais, A., Gjinovci, A., Huarte, J., Bauquis, J., Nadal, A., Martín, F., et al., 2000. Junctional communication of pancreatic beta cells contributes to the control of insulin secretion and glucose tolerance. J Clin Invest. 106(2):235-43.

Chen, C., Hosokawa, H., Bumbalo, L.M., Leahy, J.L., 1994. Mechanism of compensatory hyperinsulinemia in normoglycemic insulin-resistant spontaneously hypertensive rats. Augmented enzymatic activity of glucokinase in beta-cells. J Clin Invest. 94(1):399-404.

Chen, N.G., Tassava, T.M., Romsos, D.R., 1993. Threshold for glucose-stimulated insulin secretion in pancreatic islets of genetically obese (ob/ob) mice is abnormally low. J Nutr. 123(9):1567-1574.

Coleman, D.L., 1978. Obese and diabetes: two mutant genes causing diabetes-obesity syndromes in mice. Diabetologia. 14(3):141-8.

Colsoul, B., Jacobs, G., Philippaert, K., Owsianik, G., Segal, A., Nilius, B., et al., 2014. Insulin downregulates the expression of the Ca2+-activated nonselective cation channel TRPM5 in pancreatic islets from leptin-deficient mouse models. Pflugers Arch. 466(3):611-21.

Colsoul, B., Schraenen, A., Lemaire, K., Quintens, R., Van Lommel, L., Segal, A., et al., 2010. Loss of high-frequency glucose-induced Ca2+ oscillations in pancreatic islets correlates with impaired glucose tolerance in Trpm5-/- mice. Proc Natl Acad Sci U S A. 107(11):5208-13.

Fink, B.D., Hong, Y.S., Mathahs, M.M., Scholz, T.D., Dillon, J.S., Sivitz, W.I., 2002. UCP2-dependent proton leak in isolated mammalian mitochondria. J Biol Chem. 277(6):3918-25. 
Fournier, L., Whitfield, J.F., Xiang, H., Schwartz, J.L., Bégin-Heick, N., 1993. K+ channel and alpha 2-adrenergic effects on glucose-induced Ca2+i surges: aberrant behavior in ob/ob mice. Am J Physiol. 264(6 Pt 1):C1458-65.

Fournier, L.A., Heick, H.M., Bégin-Heick, N., 1990. The influence of K(+)-induced membrane depolarization on insulin secretion in islets of lean and obese (ob/ob) mice. Biochem Cell Biol. 68(1):243-8.

Gepts, W., Christophe, J., Mayer, J., 1960. Pancreatic islets in mice with the obesehyperglycemic syndrome: lack of effect of carbutamide. Diabetes. 9:63-9.

Gonzalez, A., Merino, B., Marroquí, L., Ñeco, P., Alonso-Magdalena, P., CaballeroGarrido, E., et al., 2013. Insulin hypersecretion in islets from diet-induced hyperinsulinemic obese female mice is associated with several functional adaptations in individual $\beta$-cells. Endocrinology. 154(10):3515-24.

Göpel, S., Kanno, T., Barg, S., Galvanovskis, J., Rorsman, P., 1999. Voltage-gated and resting membrane currents recorded from B-cells in intact mouse pancreatic islets. J Physiol. 15;521 Pt 3:717-28.

Göpel, S., Zhang, Q., Eliasson, L., Ma, X.S., Galvanovskis, J., Kanno, T., et al., 2004. Capacitance measurements of exocytosis in mouse pancreatic alpha-, beta- and delta-cells within intact islets of Langerhans. J Physiol. 556(Pt 3):711-26.

Göpel, S.O., Kanno, T., Barg, S., Rorsman, P., 2000. Patch-clamp characterisation of somatostatin-secreting -cells in intact mouse pancreatic islets. J Physiol. 528(Pt 3):497-507.

Grapengiesser, E., Gylfe, E., Hellman, B., 1988. Glucose-induced oscillations of cytoplasmic $\mathrm{Ca} 2+$ in the pancreatic beta-cell. Biochem Biophys Res Commun. 151(3):1299-304.

Hellman, B., 1965. Studies in obese-hyperglycemic mice. Ann N Y Acad Sci. 1965 Oct 8;131(1):541-58.

Hellman, B., 1970. Methodological approaches to studies on the pancreatic islets. Diabetologia. 1970 Apr;6(2):110-20.

Henquin, J.C., 2009. Regulation of insulin secretion: a matter of phase control and amplitude modulation. Diabetologia. 52(5):739-751.

Houamed, K.M., Sweet, I.R., Satin, L.S., 2010. BK channels mediate a novel ionic mechanism that regulates glucose-dependent electrical activity and insulin secretion in mouse pancreatic beta-cells. J Physiol 588:3511-3523.

Hull, R.L., Kodama, K., Utzschneider, K.M., Carr, D.B., Prigeon, R.L., Kahn SE., 2005. Dietary-fat-induced obesity in mice results in beta cell hyperplasia but not increased insulin release: evidence for specificity of impaired beta cell adaptation. Diabetologia. 48(7):1350-8.

Ivarsson, R., Quintens, R., Dejonghe, S., Tsukamoto, K., in 't Veld, P., Renström, E., et al., 2005. Redox control of exocytosis: regulatory role of NADPH, thioredoxin, and glutaredoxin. Diabetes. 54(7):2132-42.

Jacobson, D.A., Mendez, F., Thompson, M., Torres, J., Cochet, O., Philipson, L.H., 2010. Calcium-activated and voltage-gated potassium channels of the pancreatic islet impart distinct and complementary roles during secretagogue induced electrical responses. J Physiol 588:3525-3537.

Jetton, T.L., Liang, Y., Cincotta, A.H., 2001. Systemic treatment with sympatholytic dopamine agonists improves aberrant beta-cell hyperplasia and GLUT2, glucokinase, and insulin immunoreactive levels in ob/ob mice. Metabolism. 50(11):1377-84.

Kahn, S.E., Hull, R.L., Utzschneider, K.M., 2006. Mechanisms linking obesity to insulin resistance and type 2 diabetes. Nature 444:840-846. 
Kargar, C., Ktorza, A., 2008. Anatomical versus functional beta-cell mass in experimental diabetes. Diabetes Obes Metab. 10 Suppl 4:43-53.

Kou, K., Saisho, Y., Satoh, S., Yamada, T., Itoh, H., 2013. Change in $\beta$-cell mass in Japanese nondiabetic obese individuals. J Clin Endocrinol Metab. 98(9):3724-3730.

MacDonald, P.E., 2011. Signal integration at the level of ion channel and exocytotic function in pancreatic $\beta$-cells. Am J Physiol Endocrinol Metab. 301(6):E1065-9.

Maechler, P., Wollheim, C.B., 1999. Mitochondrial glutamate acts as a messenger in glucose-induced insulin exocytosis. Nature. 402(6762):685-9.

Martin, F., Sanchez-Andres, J.V., Soria, B., 1995. Slow [Ca2+]i oscillations induced by ketoisocaproate in single mouse pancreatic islets. Diabetes. 44(3):300-5.

Nadal, A., Quesada, I., Soria, B., 1999. Homologous and heterologous asynchronicity between identified alpha-, beta- and delta-cells within intact islets of Langerhans in the mouse. J Physiol. 517 (Pt 1):85-93.

Park, S.H., Ryu, S.Y., Yu, W.J., Han, Y.E., Ji, Y.S., Oh, K., Sohn, J.W., et al., 2013. Leptin promotes K(ATP) channel trafficking by AMPK signaling in pancreatic $\beta$ cells. Proc Natl Acad Sci U S A. 110(31):12673-8.

Patterson, G.H., Knobel, S.M., Arkhammar, P., Thastrup, O., Piston, D.W., 2000. Separation of the glucose-stimulated cytoplasmic and mitochondrial NAD(P)H responses in pancreatic islet beta cells. Proc Natl Acad Sci U S A. 97(10):5203-7.

Quesada, I., Fuentes, E., Andreu, E., Meda, P., Nadal, A., Soria, B., 2003. On-line analysis of gap junctions reveals more efficient electrical than dye coupling between islet cells. Am J Physiol Endocrinol Metab. 284(5):E980-7.

Quesada, I., Martín, F., Soria, B., 2000. Nutrient modulation of polarized and sustained submembrane Ca2+ microgradients in mouse pancreatic islet cells. J Physiol. 525 Pt 1:159-67.

Quesada, I., Todorova, M.G., Alonso-Magdalena, P., Beltrá, M., Carneiro, E.M., Martin, F., ET al., 2006. Glucose induces opposite intracellular Ca2+ concentration oscillatory patterns in identified alpha- and beta-cells within intact human islets of Langerhans. Diabetes. 55(9):2463-9.

Quesada, I., Todorova, M.G., Soria, B., 2006. Different metabolic responses in alpha-, beta-, and delta-cells of the islet of Langerhans monitored by redox confocal microscopy. Biophys J. 90(7):2641-50.

Rafacho, A., Marroquí, L., Taboga, S.R., Abrantes, J.L., Silveira, L.R., Boschero, A.C., et al., 2010. Glucocorticoids in vivo induce both insulin hypersecretion and enhanced glucose sensitivity of stimulus-secretion coupling in isolated rat islets. Endocrinology. 151(1):85-95.

Rahier, J., Guiot, Y., Goebbels, R.M., Sempoux, C., Henquin, J.C., 2008. Pancreatic beta-cell mass in European subjects with type 2 diabetes. Diabetes Obes Metab. 10 Suppl 4:32-42.

Ravier, M.A., Sehlin, J., Henquin, J.C., 2002. Disorganization of cytoplasmic Ca(2+) oscillations and pulsatile insulin secretion in islets from ob/ob mice. Diabetologia. 45(8):1154-63.

Reinbothe, T.M., Ivarsson, R., Li, D.Q., Niazi, O., Jing, X., Zhang, E., Stenson, L., Bryborn, U., Renström., E., 2009. Glutaredoxin-1 mediates NADPH-dependent stimulation of calcium-dependent insulin secretion. Mol Endocrinol. 23(6):893900.

Rorsman, P., Braun, M., 2013. Regulation of insulin secretion in human pancreatic islets. Annu Rev Physiol. 75:155-79. 
Rosario, L.M., Atwater, I., Rojas, E., 1985. Membrane potential measurements in islets of Langerhans from ob/ob obese mice suggest an alteration in [Ca2+]i-activated $\mathrm{K}+$ permeability. Q J Exp Physiol. 70(1):137-50.

Rosario, L.M., 1985. Differential effects of the $\mathrm{K}+$ channel blockers apamin and quinine on glucose-induced electrical activity in pancreatic beta-cells from a strain of ob/ob (obese) mice. FEBS Lett. 188(2):302-6.

Sachdeva, M.M., Stoffers, D.A., 2009. Minireview: Meeting the demand for insulin: molecular mechanisms of adaptive postnatal beta-cell mass expansion. Mol Endocrinol. 23(6):747-58.

Saisho, Y., Butler, A.E., Manesso, E., Elashoff, D., Rizza, R.A., Butler, P.C., 2013. $\beta$ cell mass and turnover in humans: effects of obesity and aging. Diabetes Care. 2013 36(1):111-7.

Saleh, M.C., Wheeler, M.B., Chan, C.B., 2006. Endogenous islet uncoupling protein-2 expression and loss of glucose homeostasis in ob/ob mice. J Endocrinol. 190(3):659-67.

Seino, S., Shibasaki, T., Minami, K., 2011. Dynamics of insulin secretion and the clinical implications for obesity and diabetes. J Clin Invest. 121(6):2118-25.

Solomon, G., Atkins, A., Shahar, R., Gertler, A., Monsonego-Ornan. E, 2014. Effect of peripherally administered leptin antagonist on whole body metabolism and bone microarchitecture and biomechanical properties in the mouse. Am J Physiol Endocrinol Metab. 306(1):E14-27.

Tripathy, S., Torres-Gonzalez, M., Jump, D.B., 2010. Elevated hepatic fatty acid elongase-5 activity corrects dietary fat-induced hyperglycemia in obese C57BL/6J mice. J Lipid Res. 51(9):2642-54.

Tomita, T., Doull, V., Pollock, H.G., Krizsan, D., 1992. Pancreatic islets of obese hyperglycemic mice (ob/ob). Pancreas. 7(3):367-75.

Vozzi, C., Ullrich, S., Charollais, A., Philippe, J., Orci, L., Meda, P., 1995. Adequate connexin-mediated coupling is required for proper insulin production. J Cell Biol. 131(6 Pt 1):1561-72.

Weir, G.C., Bonner-Weir, S., 2004. Five stages of evolving beta-cell dysfunction during progression to diabetes. Diabetes. 53 Suppl 3:S16-21.

Westman, S., 1968a. The endocrine pancreas of old obesehyperglycemic mice. Acta Soc Med Ups. 73(1):81-9.

Westman, S., 1968b. Development of the obese-hyperglycaemic syndrome in mice. Diabetologia. 4(3):141-9. 
FIGURE LEGENDS.

Figure 1. Metabolic features in control and ob/ob mice. A, Body weight ( $\mathrm{n}=35$ and $\mathrm{n}=28$ for control and $o b / o b$ mice, respectively). B, Plasma glucose in the fed state in CTL ( $\mathrm{n}=26)$ and $o b / o b$ mice $(\mathrm{n}=23) . \mathrm{C}$, Plasma insulin in the fed state in CTL $(\mathrm{n}=13)$ and $o b / o b$ mice $(\mathrm{n}=11)$. $\mathrm{D}$, Insulin resistance calculated by HOMA-IR in CTL $(\mathrm{n}=8)$ and $o b / o b$ mice ( $\mathrm{n}=6)$. E, Glucose tolerance test ( $\mathrm{n}=8$ for CTL and $\mathrm{n}=7$ for $o b / o b$ mice). F, Area under the curve from experiment in E. G and H, Plasma glucose $(G)$ and insulin (H) measured in CTL $(n=8)$ and $o b / o b(n=6)$ just before an i.p. glucose load and 30 min after. Statistical significance is indicated: $*, \mathrm{p} \leq 0.05 ; * *, \mathrm{p} \leq 0.01 ; * * *, \mathrm{p} \leq 0.001 ; \mathrm{ns}$, nonsignificant. at increasing glucose concentrations (percentage referred to the signal in the basal condition: $0.5 \mathrm{mM}$ glucose). The trace represents the average of 6 different experiments per group. $B$, The graph represents the mean \pm SEM of the maximal $N A D(P) H$ autofluorescence values at the end of each glucose stimulus shown in A. C, Mean \pm SEM of the maximal NAD(P)H autofluorescence values at each glucose concentration, normalized in each group from 0 to $100 \%$. The value of the glucose concentration to reach half the maximal fluorescence in each group is indicated in the graph. D, Changes in Rhod123 fluorescence at increasing glucose concentrations. The trace represents the average of 8 and 9 different experiments in CTL and ob/ob, respectively. E, Mean \pm SEM of the minimal Rhod123 fluorescence values at the end of each glucose stimulus. F, Mean \pm SEM of the minimal Rhod123 fluorescence values at each glucose concentration, normalized in each group from 0 to $100 \%$. G, Changes in NAD(P)H autofluorescence at increasing glucose concentrations in CTL $(\mathrm{n}=20)$ and $o b / o b(\mathrm{n}=66)$ 
isolated cells. $\mathrm{H}$, Mean \pm SEM of the maximal $\mathrm{NAD}(\mathrm{P}) \mathrm{H}$ autofluorescence values at the end of each glucose stimulus from experiment in G. Statistical significance is indicated: $*, \mathrm{p} \leq 0.05 ; * *, \mathrm{p} \leq 0.01 ; * * *, \mathrm{p} \leq 0.001 ; \mathrm{ns}$, non-significant.

Figure 3. Electrical activity in control and $\boldsymbol{o b} / \boldsymbol{o b} \boldsymbol{\beta}$-cells. A and B, Representative examples of membrane potential changes in response to $11 \mathrm{mM}$ glucose in CTL (A; $\mathrm{n}=6)$ and $o b / o b(\mathrm{~B} ; \mathrm{n}=6) \beta$-cells. Recordings were performed in beta-cells within intact islets. C, D and E, Firing frequency (C), burst duration (D) and interburst duration (E) from experiments shown in A and B. F and G, Detail of figures A and B, respectively, at expanded temporal scale. H, I, J, Burst baseline (H), action potential baseline (I) and mean peak voltage of the action potentials $(J)$ from recordings shown in $F$ and $G(n=5$ for CTL and $\mathrm{n}=6$ for $o b / o b)$. Statistical significance is indicated: *, $\mathrm{p} \leq 0.05 ; * *, \mathrm{p} \leq 0.01$.

Figure 4. Glucose-induced $\mathrm{Ca}^{2+}$ signaling in $\beta$-cells of control and $o b / o b$ mice. A, Representative intracellular $\mathrm{Ca}^{2+}$ signals measured in intact CTL (n=8) and $o b / o b(\mathrm{n}=6)$ islets by fluorescence microscopy and fura-2 in response to $8 \mathrm{mM}$ and $16 \mathrm{mM}$ glucose. $\mathrm{B}$, Representative intracellular $\mathrm{Ca}^{2+}$ signals measured in intact CTL $(\mathrm{n}=9)$ and $o b / o b$ $(\mathrm{n}=8)$ islets in response to $5.6 \mathrm{mM}$ and $8 \mathrm{mM}$ glucose. C, Analysis of the area under the curve on the last five minutes of each glucose stimulus from experiments shown in A and B. D, Analysis of the fluorescence increase $(\Delta \mathrm{F})$ of the first $\mathrm{Ca}^{2+}$ transient in response to each glucose challenge from experiments shown in A and B. E, Percentage of responsive islets to $5.6 \mathrm{mM}$ glucose ( $\mathrm{n}=9$ for CTL; $\mathrm{n}=8$ for $\mathrm{ob} / \mathrm{ob}$ ). All the islets from both groups responded to 8 and $16 \mathrm{mM}$ glucose. F, Oscillations per minute in CTL and ob/ob islets at 8 and $16 \mathrm{mM}$ glucose. G, Representative intracellular $\mathrm{Ca}^{2+}$ signals in response to depolarization induced by a short pulse of $\mathrm{KCl}(75 \mathrm{mM}$; $\mathrm{n}=10$ for CTL; $\mathrm{n}=6$ for $o b / o b) . H$, Analysis of the fluorescence increases $(\Delta \mathrm{F})$ shown in G. Statistical significance is indicated: * $\mathrm{p} \leq 0.05 ;{ }^{* *}, \mathrm{p} \leq 0.01 ; * * *, \mathrm{p} \leq 0.001 ; \mathrm{ns}$, non-significant. 
730 Figure 5. Insulin secretion and exocytosis. A, Insulin gene expression in islets from

731 CTL and $o b / o b(n=5)$. B, Insulin content normalized to total protein in CTL $(n=16)$ and $732 \mathrm{ob} / \mathrm{ob}(\mathrm{n}=15)$ islets. C, Representative capacitance responses to ten 500-millisecond 733 depolarizing pulses (from -70 to $0 \mathrm{mV}$ ) in CTL and $o b / o b \beta$-cells. Recordings were 734 performed in beta-cells within intact islets. D, Membrane capacitance at the end of the 735 depolarizing protocol normalized by cell size ( $\mathrm{n}=10$ for CTL; $\mathrm{n}=45$ for $o b / o b)$. 736 Statistical significance is indicated: *, $\mathrm{p} \leq 0.05 ; * *, \mathrm{p} \leq 0.01 ; * * *, \mathrm{p} \leq 0.001$; ns, non737 significant.

738 Figure 6. $\beta$-cell coupling in $\boldsymbol{o b} / \boldsymbol{o b}$ islets. A and $\mathrm{B}$, Representative $\mathrm{Ca}^{2+}$ signals in 739 several individual $\beta$-cells within a CTL (A) or an ob/ob islet (B). C, Mean time delay between the first cell that responds to $11 \mathrm{mM}$ glucose and the rest of $\beta$-cells within an

741 islet was calculated to measure the degree of $\mathrm{Ca}^{2+}$ signaling synchrony. In each 742 experimental group, the time at which the first cell responded to high glucose was set as $743 \mathrm{t}=0$, and then, the delay of the response of the rest of cells of the same islet was 744 determined. $\mathrm{D}$, Temporal delays in the $\beta$-cell $\mathrm{Ca}^{2+}$ response to glucose. The mean time 745 of the response to $11 \mathrm{mM}$ glucose in CTL $\beta$-cells was set as $\mathrm{t}=0$, and then, the 746 anticipation or delay of the response of $o b / o b \beta$-cells was calculated. Statistical 747 significance is indicated: ***, $\mathrm{p} \leq 0.001$. 
Figure 1.
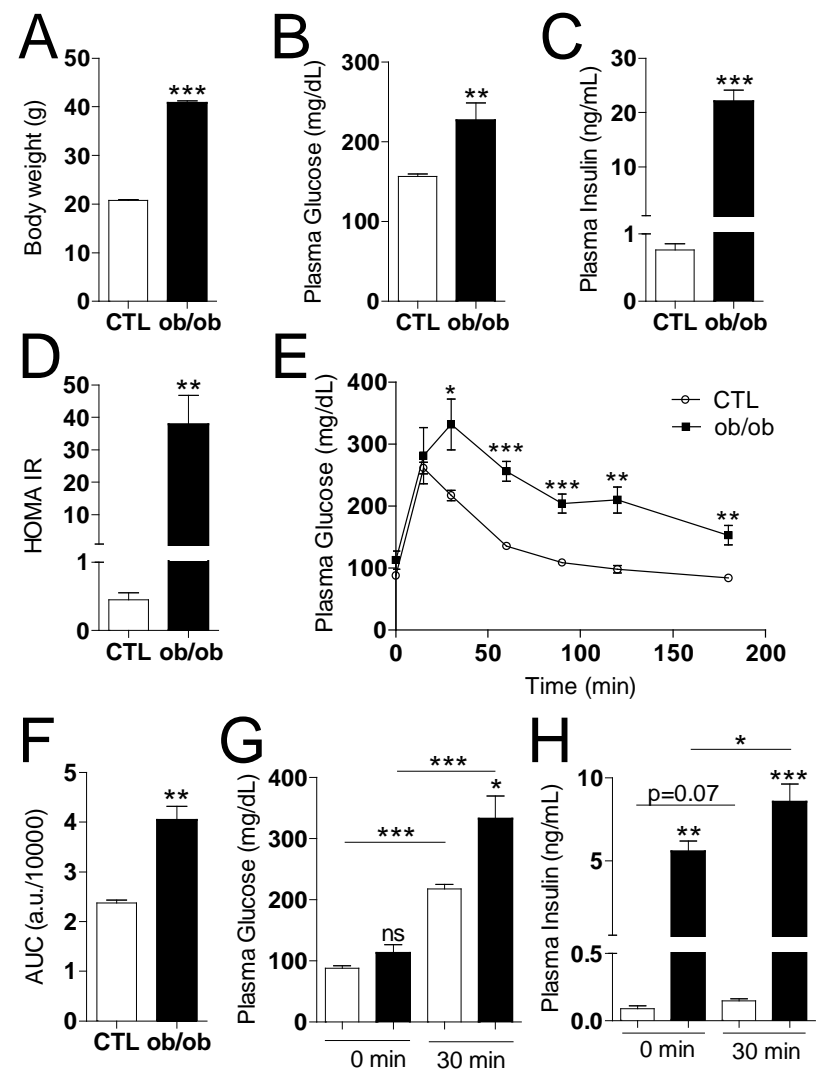
Figure 2.
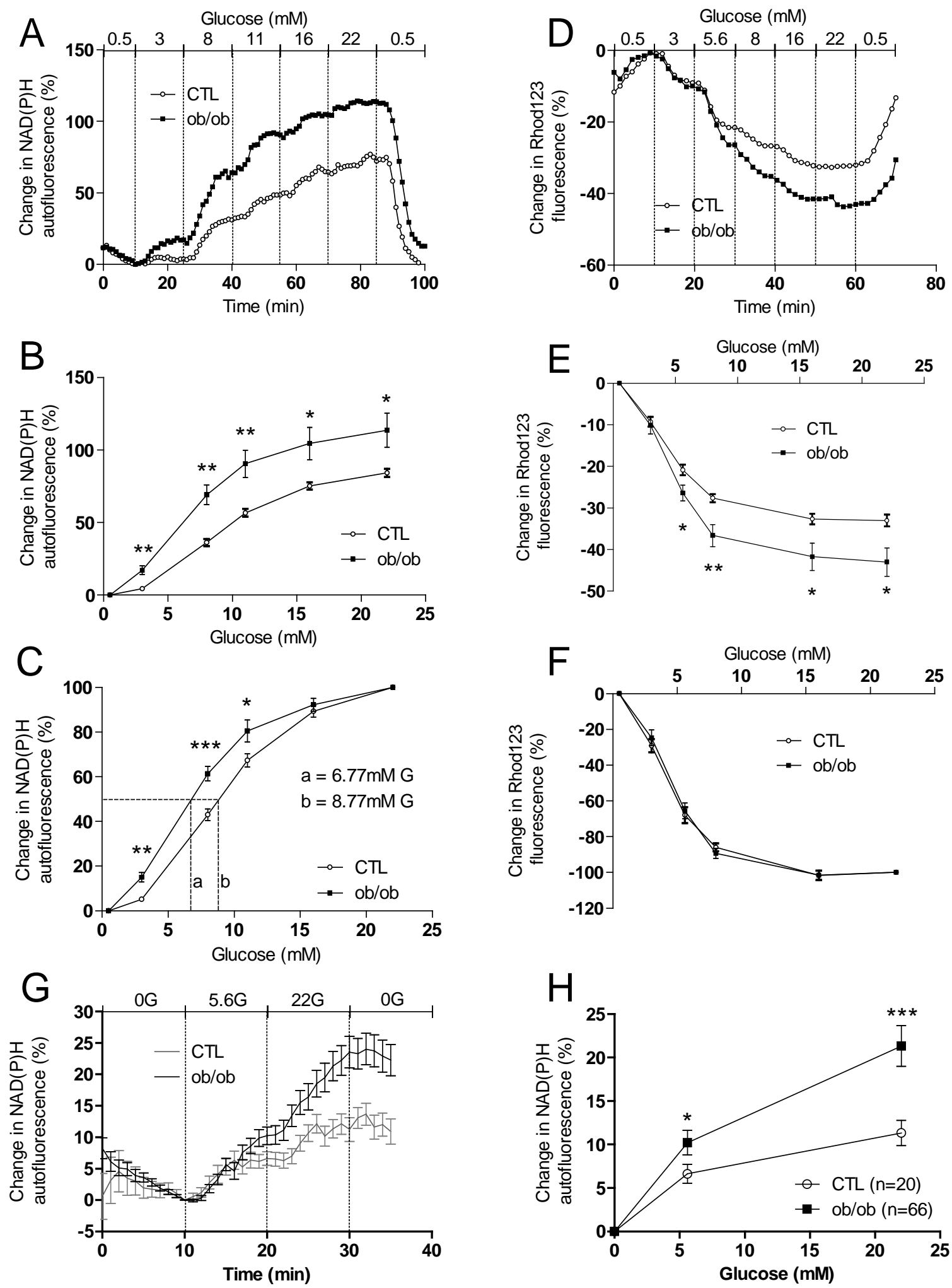
Figure 3.

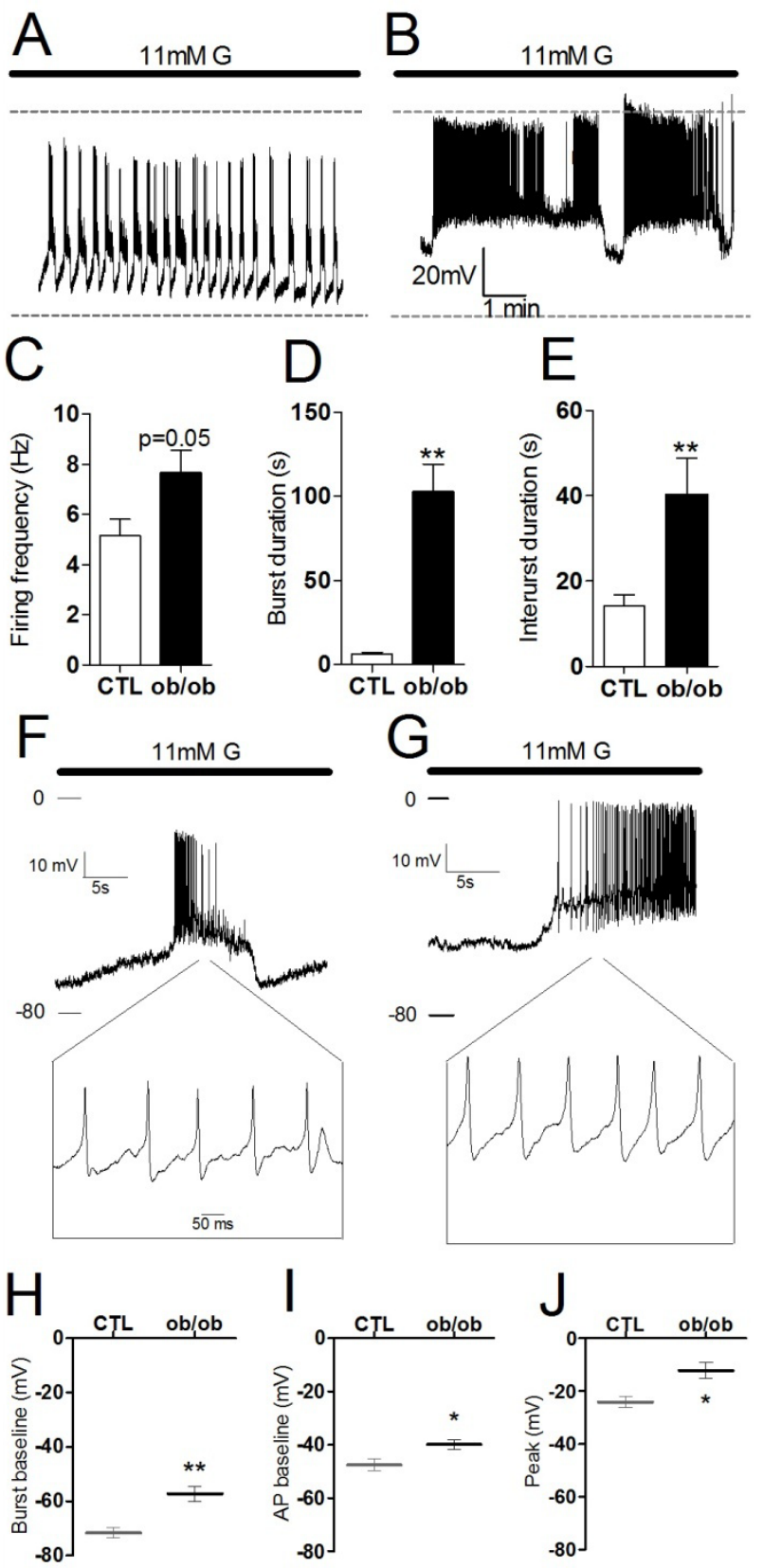


Figure 4.
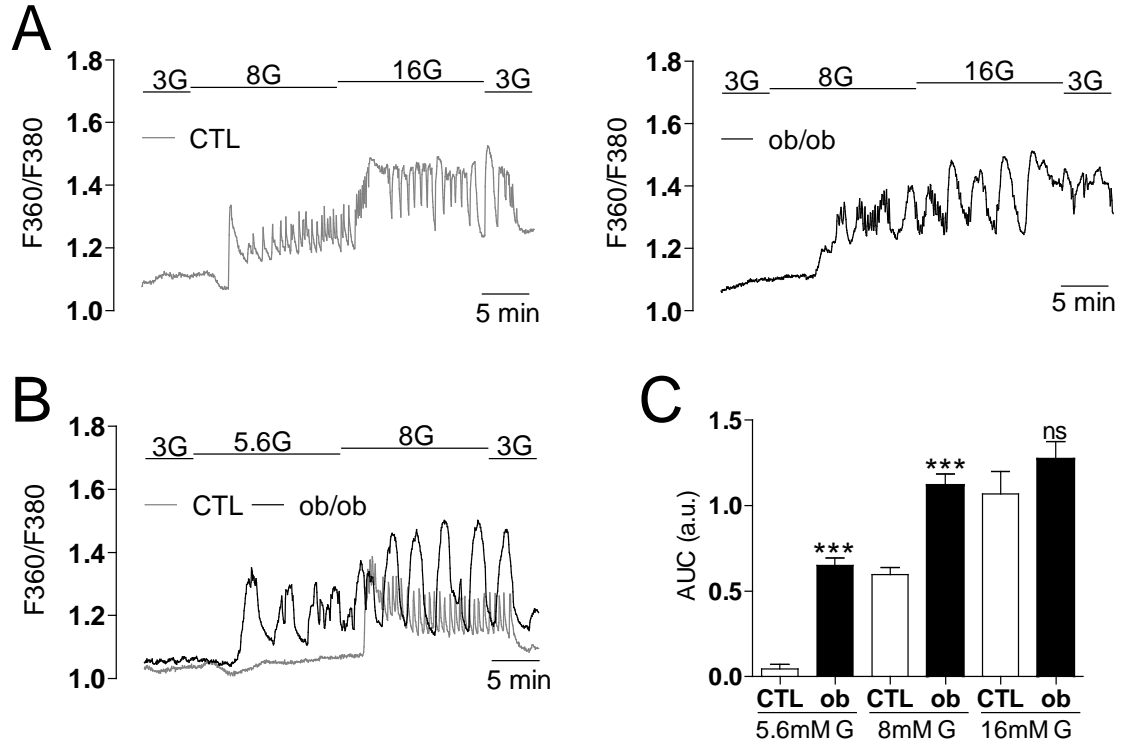

D

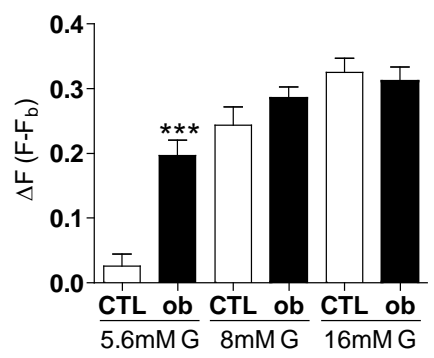

E
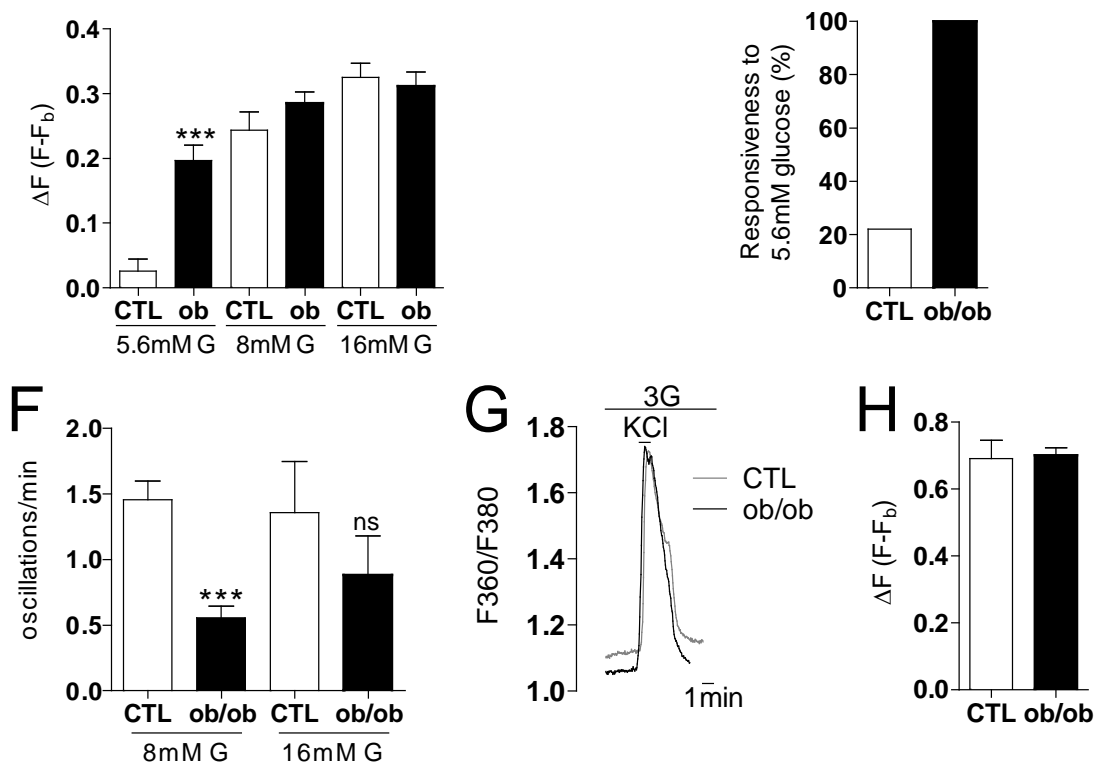
Figure 5.

A

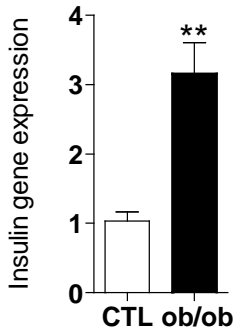

C

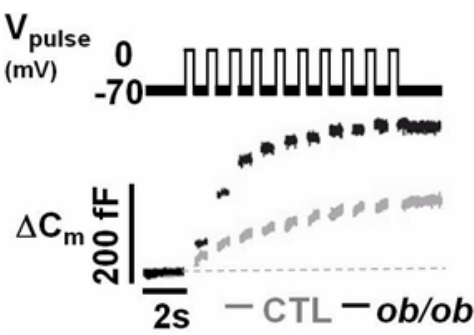

B

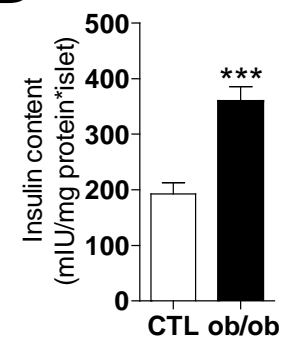

D

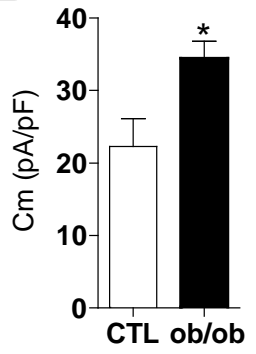


Figure 6.

A

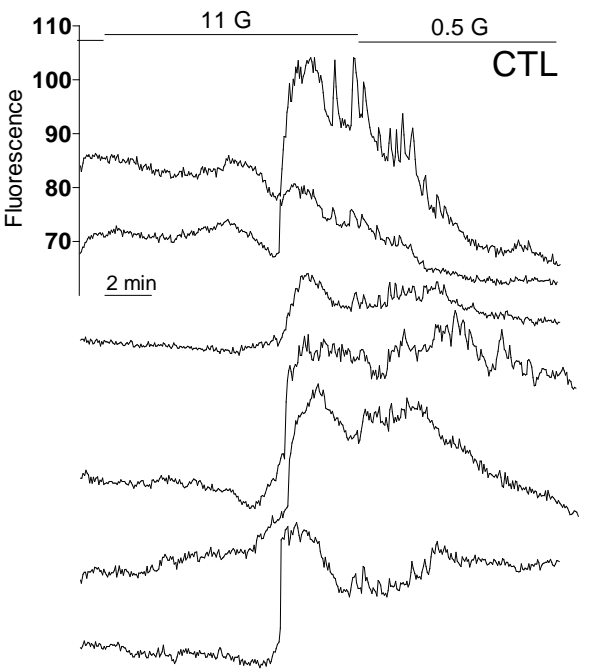

C

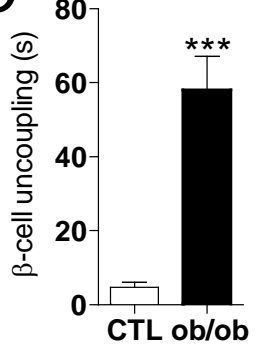

B
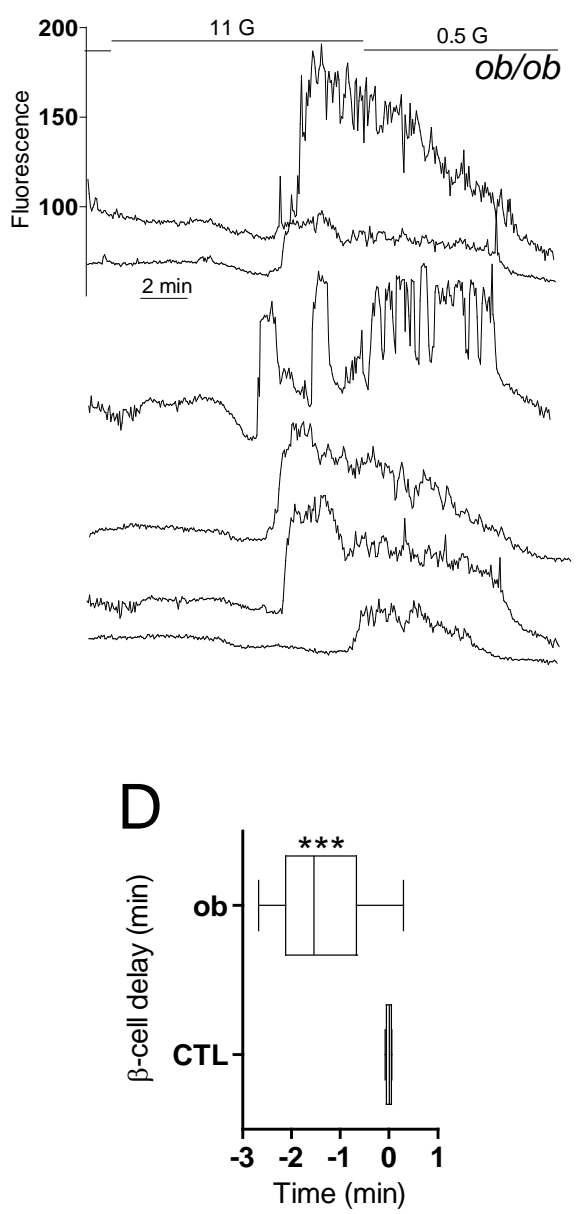
1

2 Supplemental Table 1: Sequences of the primer-pairs used for gene expression

3 analysis.

4

\begin{tabular}{|l|l|l|}
\hline & Forward 5' ${ }^{\prime}{ }^{\prime}{ }^{\prime}$ & Reverse 5’ $^{\prime}{ }^{\prime}{ }^{\prime}$ \\
\hline GAPDH & CCTGCACCACCAACTGCTTAG & GCCCCACGGCCATCACGCCA \\
\hline Insulin & AGCAGGAAGGTTATTGTTTC & ACATGGGTGTGTAGAAGAAG \\
\hline GLUT2 & GGAAGAGGCATCGACTGAGCAG & GCCTTCTCCACAAGCAGCACAG \\
\hline Glucokinase & GAAGCACACTCAGGTCTTGCTC & AAAACAGCCAGGTCTGGGCAGC \\
\hline Connexin36 & ACCATCTTGGAGAGGCTGCTGGA & ATCTTCTCGTTTGCTCCCTCCGC \\
\hline TRPM5 & CAAATCCCTCTGGATGAAATTGATG & CCAGCCAGTTGGCATAGA \\
\hline
\end{tabular}

5

6

7 
A

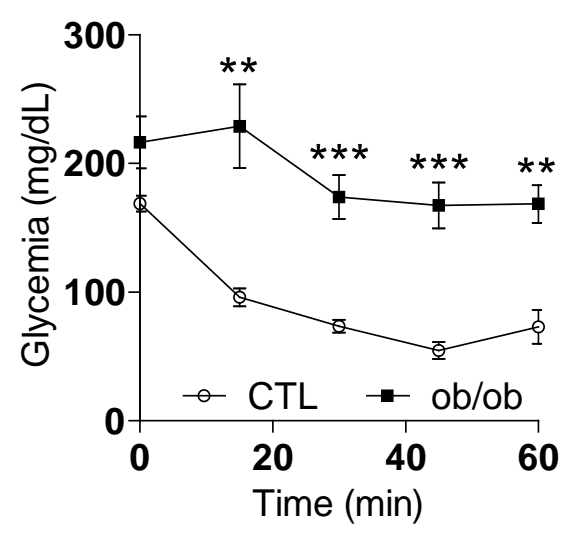

C

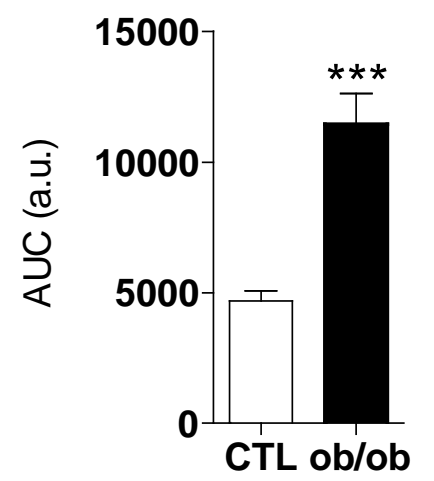

B

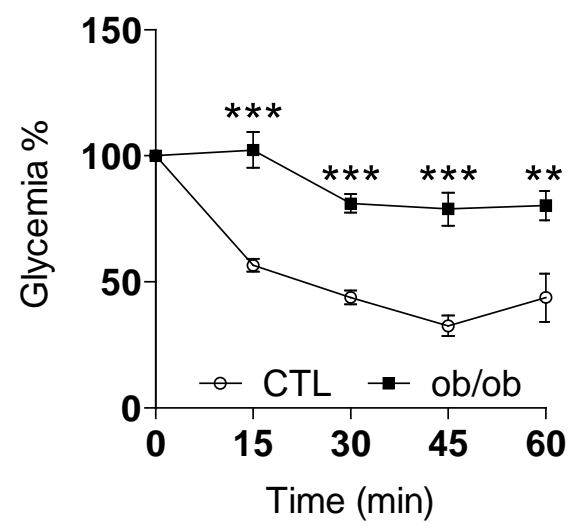

D

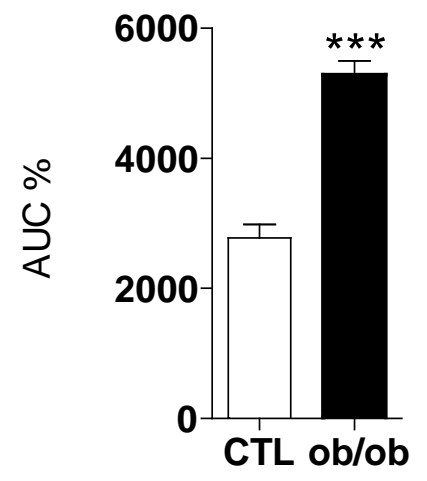

Supplemental Figure 1. Insulin sensitivity. A, Insulin tolerance test in CTL and $o b / o b$ mice ( $n=8$ for each group). B, Plasma glucose values during an insulin tolerance test, expressed as the percentage of change of the initial value. $C$ and $D$, area under the curve of $A$ and $B$, respectively. E, Plasma glucose before the insulin injection. Statistical significance is indicated: $* *, \mathrm{p} \leq 0.01 ; * * *, \mathrm{p} \leq 0.001$; 
A

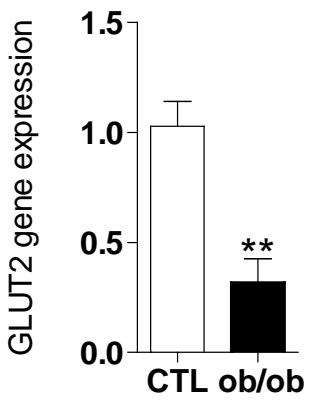

B

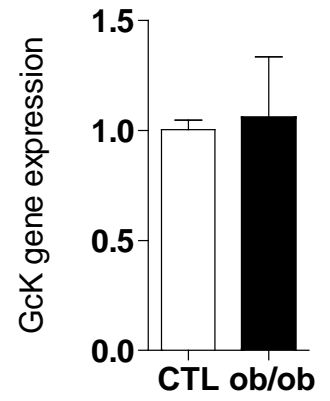

C

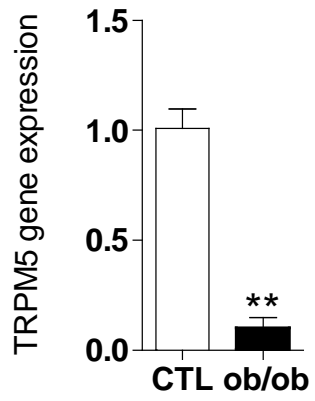

Supplemental Figure 2. Gene expression analysis by qPCR. Relative gene expression of GLUT2 (A), Glucokinase (B) and TRPM5 (C) in islets from CTL and $o b / o b$ mice ( $\mathrm{n}=5$ for each group). Statistical significance is indicated: **, $\mathrm{p} \leq 0.01$ 

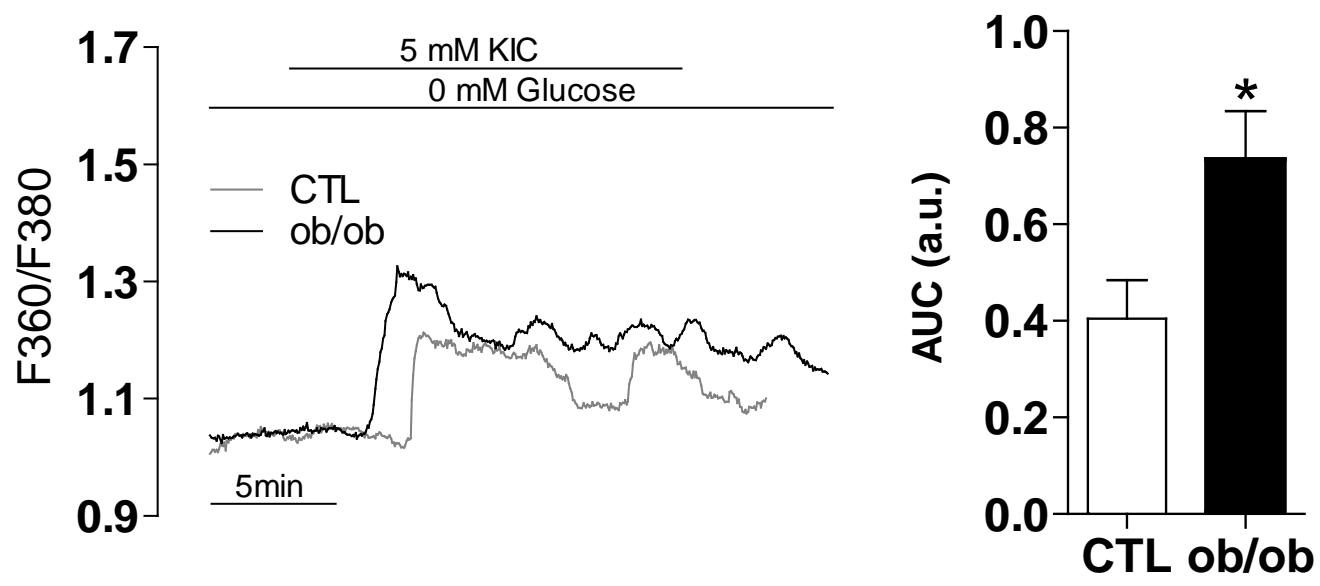

Supplemental Figure 3. $\mathrm{Ca}^{2+}$ signaling induced by the non-glucidic fuel $\alpha$-ketoisocaproate (KIC). A, Representative intracellular $\mathrm{Ca}^{2+}$ signals measured in intact CTL and $o b / o b$ islets in response to $5 \mathrm{mM}$ KIC ( $\mathrm{n}=6$ for each group). $\mathrm{B}$, Area under the curve on the last five minutes of the KIC stimulus from experiment in A. Statistical significance is indicated: *, $\mathrm{p} \leq 0.05$. 

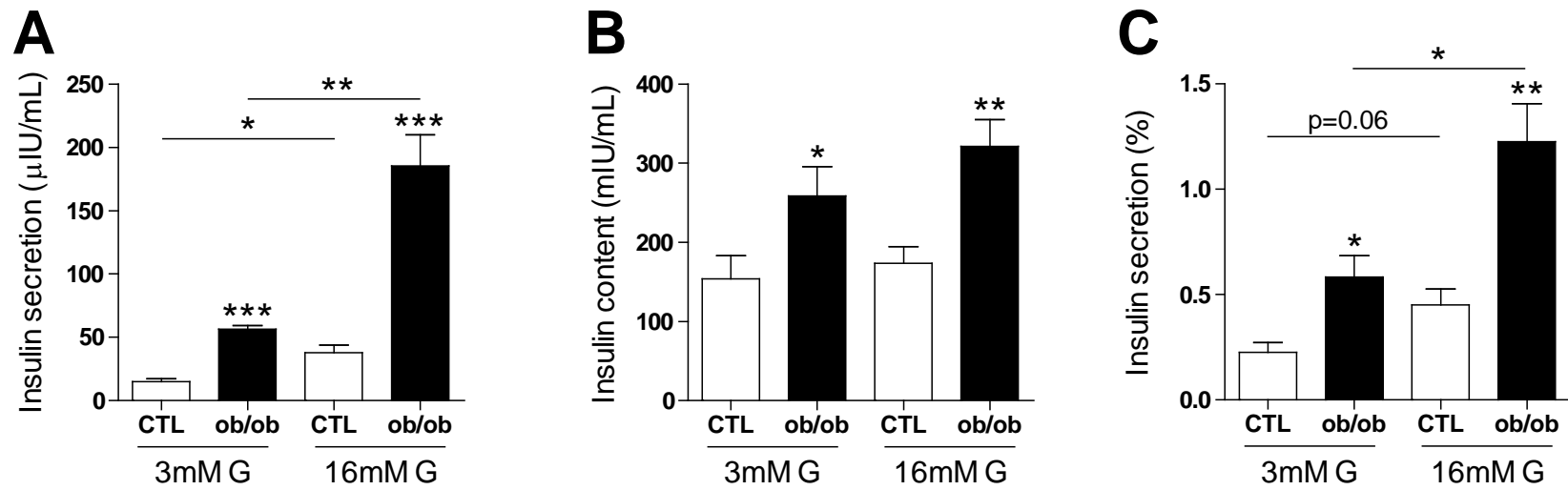

Supplemental Figure 4. Ex vivo insulin secretion from CTL and ob/ob islets. Insulin secretion (A), insulin content (B) and insulin secretion normalized by insulin content (C) in islets from CTL and ob/ob mice ( $\mathrm{n}=8$ for each group). Statistical significance is indicated: *, $\mathrm{p} \leq 0.05 ;{ }^{* *}, \mathrm{p} \leq 0.01 ; * * *, \mathrm{p} \leq 0.001 ;$ ns, non-significant. 
A

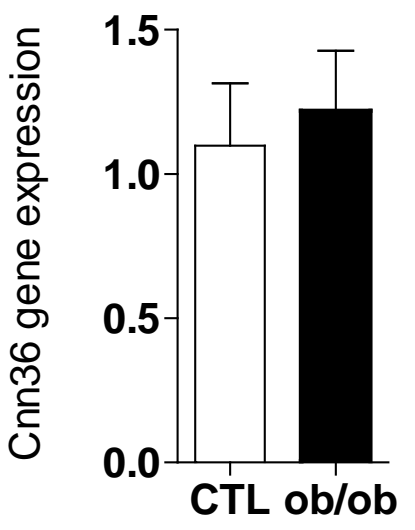

$\mathrm{B}$

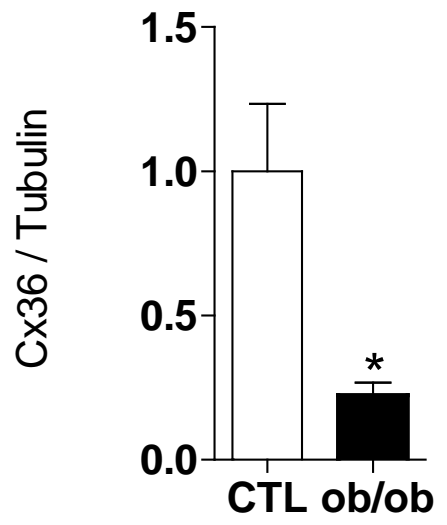

C

CTL ob/ob

Connexin36

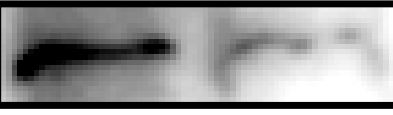

$\beta$-Tubulin

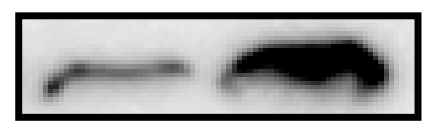

Supplemental Figure 5. Connexin36 expression. A, Connexin36 gene expression in islets of $\mathrm{CTL}$ and $o b / o b$ mice ( $\mathrm{n}=5$ for each group). $\mathrm{B}$, Connexin36 protein expression in islets of CTL $(\mathrm{n}=4)$ and $o b / o b(\mathrm{n}=3)$ mice. C, Representative blots from B. Statistical significance is indicated: $*, \mathrm{p} \leq 0.05$. 
Supplemental Figure 6.

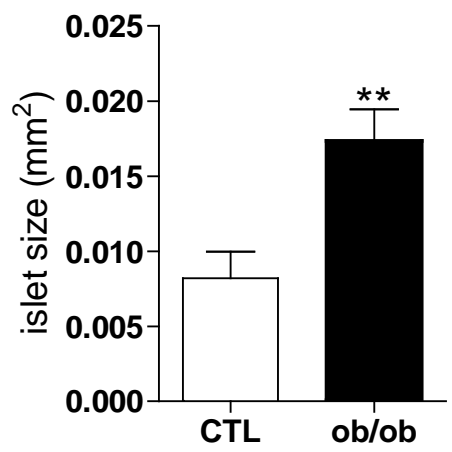

Supplemental Figure 6. Islet size. Thus graph shows the average islet size for CTL ( $\mathrm{n}=316$ islets) and $o b / o b\left(\mathrm{n}=454\right.$ islets). Statistical significance is indicated: ${ }^{* *}, \mathrm{p} \leq 0.01$ 